\title{
The Puzzle of Abu Ghraib: Are Democratic Institutions a Palliative or Panacea?
}

\author{
Christian Davenport \\ christiandavenport@mac.com \\ University of Maryland
}

\author{
Will H. Moore \\ will.moore@fsu.edu \\ Florida State University
}

\author{
Dave Armstrong \\ david.armstrong@politics.ox.ac.uk \\ Oxford University *
}

December 8, 2007

\footnotetext{
${ }^{*}$ Paper presented at the Annual Meeting of the International Studies Association, 28 February-3 March 2007, Chicago, IL and the Annual Meeting of the Peace Science Society (International), 10-12 November 2006, Columbus, OH. DISCUSSION DRAFT: Moore had last shot at this; Armstrong and Davenport have not yet had an opportunity to correct his gaffes. Victor Asal, Matt Baum, Bill Berry, Andreas Beger, Julie Brown, Sean Ehrlich, Justin Esarey, Ben Fordham, Kathleen Gallagher, Doug Gibler, Matt Golder, Sona Golder, Kristian Gleditsch, Håvard Hegre, Jason Jordan, John King, Monica Nalepa, Eric Neumayer, Chris Reenock, Jackie Rubin, Courtenay Ryals, Dave Siegel, Jeff Staton, Doug Van Belle, Joe Young, and the participants at a colloquium at the University of California, Riverside have offered useful feedback on the project. As is common, we have only been able to take limited advantage of their comments and suggestions.
} 


\begin{abstract}
The events of Abu Ghraib exposed politicians, journalists, military and law enforcement personnel, NGOs, activists and ordinary citizens to the potential brutality of state repression. Many were left stunned that the agents of a liberal democracy would perpetrate such horrific acts against individuals in the state's control. Such shock makes sense if one believes that liberal democratic institutions constrain leaders from acting on the utilitarian incentive to employ torture during interrogations. While such a belief is apparently widespread, is it consistent with the recent historical record? Extant theories of repression and global evidence about torture suggest that it is not. We distinguish among three mechanisms that might constrain the use of torture in liberal democracies: voice, veto, and freedom of expression. We then argue that voice is unlikely to have a strong effect when the state is faced with violent dissent, and that the effect of veto and freedom of expression will be substantially reduced when the state is faced with a violent challenge. To test our hypotheses we use data from 146 countries covering the years 1980-1999 and investigate the extent to which voice, veto, or freedom of expression inhibit countries' use of torture both in times of quiescence and in times when dissidents challenge the state with violence. We find that rather than being aberrant, state-sponsored torture like that in Abu Ghraib is perfectly consistent with both theory and previous experience. More specifically, democratic institutions reduce the probability that a state uses torture in only limited circumstances.
\end{abstract}


Is the use of torture by the agents of a liberal democratic state aberrant or common? Responses to the April 2004 disclosure of the acts of torture perpetrated by U.S. soldiers in Abu Ghraib prison seem to indicate a difference of opinion about this question. The revelations commanded tremendous amounts of global attention from politicians, journalists, military and law enforcement personnel, NGO activists, and ordinary citizens. The responses across these distinct communities varied significantly, highlighting different levels of surprise and outrage about what occurred as well as different explanations for why the events took place. For some, the use of torture was shocking: they could not believe that the United States in particular, and a liberal democracy in general, would engage in such reprehensible behavior. Many such people attributed the behavior to "rogue" military personnel and/or "abnormal" circumstances, suggesting that there was no systematic practice of torture employed by the U.S. government. ${ }^{1}$ For others, the events were not startling at all (e.g., Zimbardo 2007). These observers argued that the events at Abu Ghraib were not aberrant; rather, they are representative of the interrogation practices of democratic states generally, and the U.S. government in particular, especially when the people being interrogated are believed to be involved in violent challenges to the state. These charges did not simply concern recent foreign policy but also addressed earlier discussions about U.S. domestic activity concerning the treatment of "political prisoners" in the 1970s and 1980s (e.g., Zwerman 1988, 1990) as well as the general practices of U.S. officials within American prisons (e.g., Brody 2004).

The two perspectives identified above are important because they not only raise specific issues about why prisoner abuse occurred at Abu Ghraib, but more importantly raise larger questions about whether the institutions of liberal democracies (i.e., popular participation, checks on majority rule, and freedom of expression) can effectively counter an executive's incentive to torture or are palliatives that fail when the state is threatened with violent dissent.

The differences between these perspectives are quite stark. In the former view, democracies

\footnotetext{
${ }^{1}$ For example, various news reports offered the following from US government officials in May, 2004. "I want to tell the people of the Middle East that the practices that took place in that prison are abhorrent and they don't represent America," President George W. Bush (Stevenson 2004). "I would like to apologize for our nation and for our military for the small number of soldiers who committed illegal or unauthorized acts here at Abu Ghraib," Major General Geoffrey Miller (Filkens 2004). "It was pretty disgusting, not what you'd expect from Americans." Senator Norm Coleman(Chuckman 2004).
} 
rarely use this type of repression, and when it is used it can be attributed to largely idiosyncratic factors (e.g., rogue soldiers and a misunderstanding of political directives). The other perspective submits that, though democracies respond with considerably less repression than nondemocracies (Davenport 1995, Davenport and Armstrong 2004), all states have an incentive to use torture (Wantchekon and Healy 1999, Walzer 2004). This puzzling bi-modal response to the revelation of Abu Ghraib leads us to investigate the following question: Which, if any, liberal democratic institutions increase the probability that the executive ignores her incentive to resort to torture?

The solution to the puzzling bi-modal response lies in recognizing that while executives in states with liberal democratic institutions are more likely to honor their self-imposed constraints on publicly visible repressive responses to violent dissent, they have an opportunity to "cheat behind closed doors" where the public and other actors are not watching. Wantchekon \& Healy (1999) propose a model which shows that the incentive to cheat exists across all regime types, and we build on their work to argue that while democratic states will exhibit reduced rates of torture when they are not challenged with violent opposition, they will relax the prohibition when faced with violent dissident activity. Our argument clashes not only with those who blame torture on idiosyncratic causes, but also scholars who contend that liberal democracies rarely use torture (e.g., Einolf 2007).

To investigate this topic, we examine the influence of liberal democracy and dissident behavior on torture within 146 countries from 1980 to 1999. To begin, we review the literature on human rights violation-discussing what we know about why states repress and how democracy, in particular, has played a prominent role in this explanation. Next, our focus shifts to torture as a strategy of repressive behavior and the limits-if any-that liberal democratic institutions might place on executives' willingness to adopt torture. Within the third section we discuss the data and methodological techniques, and then we present the empirical results. The results largely support our expectations about the impact of liberal democratic institutions on the use of torture, but there are a couple of surprises. The takeaway message is that liberal democratic institutions are a palliative, not a panacea. In the conclusion we explore the implications of these findings for human rights/repression research, public policy and social activism. Although we 
highlight numerous issues, we submit that the most important implication of our study is that it suggests a shift away from discussions about democratic exceptionalism and rogue repressive agents to a broader discussion about the conditions under which liberal democracies engage in torture and other forms of repression. In short, the analysis compels a serious re-thinking of the relationship between regime type and repressive action.

\section{The Literature on Torture and Repression}

The literature on torture is dominated by philosophical debate (e.g., Levinson 2004), reports of abuse (e.g., Amnesty International 1984), studies of the impact of torture on victims (e.g., Quiroga and Jaranson 2005), and a large body of descriptive-historical monographs (e.g., Solzhenitsyn 1974, Ignatieff 1978, Foucault 1979, Peters 1985, Andrews 1991, Millett 1994, Rejali 1994). There is little broadly comparative research (though see Einolf 2007, Rejali 2007 for recent exceptions) and few inquiries into the cross-national correlates of torture have been conducted: only one published study is available (Hathaway 2002).

The study of torture confronts a conceptual problem-the word is applied in a variety of different ways, thereby hindering understanding. While numerous definitions have been advanced, we accept the UN's characterization where torture represents:

(a)ny act by which severe pain or suffering, whether physical or mental, is intentionally inflicted on a person for such purposes as obtaining from him or a third person information or a confession, punishing him for an act he or a third person has committed or is suspected of having committed or intimidating or coercing him or a third person, or for any reason based on discrimination of any kind, when such pain or suffering is inflicted by or at the instigation of or with the consent or acquiescence of a public official or person acting in an official capacity. ${ }^{2}$

As conceived, this includes a wide range of activities, encompassing both those that might be "dirty torture" which leaves marks on the body (e.g., beatings, branding, burning, dog

\footnotetext{
${ }^{2}$ Article 1 (1), Convention Against Torture and Other Cruel, Inhuman or Degrading Treatment of Punishment, adopted by the United Nations General Assembly Resolution 39/46 of December 1984 and entered into force on 26 June 1987.
} 
attacks, hanging by limbs, sexual assaults), those referred to as "clean torture" (e.g., submersion, suffocation, electric shocks, forced painful positions, beatings that leave no marks; see Ron 1997, Rejali 2007) and "torture lite" (e.g., denial of food/water, binding/shackling of limbs, blindfolding, water boarding, exposure to excessive heat/cold, humiliation, mock executions, rough handling, sleep deprivation, solitary confinement, stripping, and threats; see Bowden 2003). As Rejali (2007) documents, "clean torture" techniques were developed in democratic countries during the 20th Century and had diffused widely by the turn of the 21st Century. While much of the policy debate about torture in democratic countries such as the Israel or the United States centers on "torture lite," this public discussion obscures the problem of the widespread use of "clean torture" throughout all countries (Ron 1997, Rejali 2007).

\subsection{Extant Theory}

The earliest theoretical explanations for repression relied upon rather simplistic structuralist notions (e.g., Arendt 1973, Dallin and Breslauer 1970, Walter 1969). Within this work, authoritarian political systems compelled political leaders to use coercion in order to proactively eliminate challengers, create ideal citizens and/or transform political, economic and cultural systems. Later theories employed what can best be thought of as a structuralist-rationalist hybrid (e.g., Gartner and Regan 1996, Gurr 1986, Lichbach 1987, Stohl 1983, Wantchekon and Healy 1999). This work argues that political authorities engage in a decision calculus where they assess the costs, benefits, probability of success, and existing alternatives to coercion before deciding whether or not and at what level to use state repression. If the perceived benefits (behavioral quiescence and political survival) outweigh the expected costs (forgone political legitimacy and resources), the probability of successfully using repressive behavior was high (e.g., because of some technological innovation) and alternative mechanisms of control were limited (e.g., normative influence), then repressive behavior was likely. If, however, the anticipated costs outweighed the expected benefits, the probability of successfully applying repression was low, and alternative mechanisms of control were readily available, then repressive behavior was unlikely.

Both approaches contend that democratic institutions reduce a state's reliance on repression. 
Drawing upon the literature in comparative politics (e.g., "new institutionalism" and "democratic performance") as well as research in international relations (the "democratic peace"), the pacifying influence of this type of political system is largely attributed to the cost that it imposes on government personnel who engage in relevant activity. ${ }^{3}$

This literature has tended to treat democracy as a whole: rather than disaggregate the specific institutions that might change an executive's decision to use repression, democracy has largely been treated as a single institution. Our reading of the literature suggests that the implicit mechanism underlying most of this work is the ballot: popular suffrage might serve as a check on executive authority. Following the direction charted by Davenport and Armstrong (2004), Bueno de Mesquita et al. (2005), Gates et al. (2006) and Davenport (2007b) we eschew that conceptualization in favor of a liberal conceptualization of democracy (see below) that focuses on three mechanisms that might reduce an executive's incentive to engage in torture: voice (i.e., suffrage and contestation), veto (i.e., separation of powers), and freedom of expression (i.e., the ability to criticize). Doing so permits us to make explicit what we believe are the mechanisms people implicitly have in mind when they argue that liberal democracy reduces the use of repression, but also allows us to build on those mechanisms to propose hypotheses explaining why the human rights activists were correct to expect that liberal democratic institutions have a palliative impact on the use of torture. We then appeal to data covering the period 1981-1999 to test our expectations.

\subsection{Extant Findings}

An absence of relevant data has limited our ability to examine the correlates of torture. Historically, most databases on repression have ignored torture (e.g., Fein 1995, Harff 2003, Taylor and Jodice 1983). More recent data collection efforts have generally included torture as one of many different types of repressive behavior considered at the same time (e.g., Cingranelli and Richards 1999a, Mitchell and McCormick 1988, Poe and Tate 1994, Gibney and Dalton

\footnotetext{
${ }^{3}$ There are numerous explanations offered for the pacifying influence of democracy on repression but this is the most compelling (Rosato 2003, Gates et al. 2006).
} 
1996). ${ }^{4}$ Only in the past few years have the diverse components of repression been disaggregated so that torture - as one type of violation, could be identified and examined relative to other forms of repressive behavior (Cingranelli and Richards 2004b), and it was only a few years prior that Hathaway (2002) created the first cross-national database specifically focused on the use of torture. We briefly review the three studies of the cross-national correlates of torture (Hathaway 2002, Gilligan and Nesbitt 2006, Powell and Staton 2007) before turning our attention to the broader literature on repression.

Using a five-point scale of torture generated from State Department Country Reports, Hathaway examined 165 countries from 1985 to 1998 with a fairly standard human rights model that included a measure of democratic institutions. She was most interested in the influence of human rights treaty ratification, and found that ratification of the Convention Against Torture (CAT) only reduces the use of torture among democracies. ${ }^{5}$ In other words, signing a treaty had no influence on state torture and, indeed, in certain cases it made it worse, unless the regime had reached the highest levels of democratic government. ${ }^{6}$

Gilligan and Nesbitt (2006) report the same findings at the system level. They are interested in the impact of norms and thus focus on the impact that the percentage of states that have ratified the CAT has on each state's likelihood of using torture (they control for whether each individual state has signed the CAT). They find that the global proportion of signatories either has no effect or, in several specifications, actually increases the likelihood that a state uses torture. Further, whether an individual state is a signatory has no effect on torture probability, but democratic states do have a lower probability.

Following related work by Hathaway (2003, 2004), Powell and Staton (2007) study compliance with the Convention Against Torture and report that the effectiveness of a state's judiciary is a key variable for understanding the intersection of ratification and compliance. They argue

\footnotetext{
${ }^{4}$ Cingranelli and Richards (1999b) is an early publication using disaggregated physical integrity rights data from what became the CIRI data set (discussed below), but while they examine the global trend in torture during the post cold war period, they only report the correlates of political imprisonment.

${ }^{5}$ More specifically, Hathaway uses an interaction term between ratification and "full democracy," which she defines as a country-year with a Polity score $>7$.

${ }^{6}$ Hathaway's finding is generally consistent with the work of Davenport and Armstrong (2004) and Bueno de Mesquita et al. (2005) who maintain that only the highest level of democratic institutions reduce repression, a point to which we return below.
} 
that states that have weak judiciaries will ratify the treaty and fail to comply. States with strong judiciaries, on the other hand, will decline to ratify for fear that their ability to use coercion during interrogation will be constrained by domestic courts. ${ }^{7}$ Both Hathaway $(2003,2004)$ and Powell and Staton (2007) thus argue, and produce evidence to support their arguments, that treaties have no effect because those states that can ignore them are considerably more likely to sign, and those that cannot ignore their treaty commitments are considerably less likely to sign. This work also suggests that the reported relationship between democracy and torture is based on a mis-specification (i.e., was produced by the failure to appreciate the selection effect).

Beyond the Hathaway, Gilligan and Nesbitt, and Powell and Staton studies there is a considerable literature on state repression and human rights violations (e.g., Bueno de Mesquita et al. 2005, Cingranelli and Richards 1999a, Davenport 1995, 1999, Davenport and Armstrong 2004, Fein 1995, Hibbs 1973, Krain 1997, Mitchell and McCormick 1988, Poe and Tate 1994, Regan and Henderson 2002, Zanger 2000). All of these studies have found that democracy decreases human rights violations. ${ }^{8}$ This, and similar, findings are commonly referred to as the "domestic democratic peace" (Hegre et al. 2001).

Like Hathaway (2002) the domestic democratic peace seems to favor the first characterization offered above: torture is the product of a "few bad apples." Yet, because they conceptually and operationally combine distinguishable forms of repression these studies fail to shed light on the differential use of particular techniques.

Finally, few of these studies considered the possibility that context matters: they do not examine the possibility that violent dissent has a conditional impact on the use of repression. Yet Davenport (1995) reports that while all regimes respond to violent dissent with repression, states with democratic institutions employ lower levels of repression than non-democratic states. Unlike the other research on this topic, his finding is ambivalent toward the question asked here. On the one hand it suggests that democratic institutions have a negative impact on repression. On the other hand, however, it demonstrates that states with democratic institutions respond to violence with repression, but do so at lower levels. We build on that ambivalence to ask whether

\footnotetext{
${ }^{7}$ See, also, Abbott and Snidal (2000, 432-3) for a similar argument.

${ }^{8}$ Two exceptions-Davenport (1997) and Richards (1999)-report that elections fail to reduce levels of human rights violations, a finding to which we return below.
} 
democratic institutions are palliative when it comes to torture: they "reduce the symptoms" under some conditions, but fail to "cure the disease."

\section{Liberal Democratic Institutions and Torture}

We begin by developing the implicit claims supporting the expectation that liberal democracies will eschew torture. To do so we lay out an explicit argument about the mechanisms that might eliminate an executive's incentive to use torture. Our argument advances four claims. First, all states respond to violent dissent with repression, one form of which is torture. Second, all states that hold a prisoner they believe has information about planned future acts of violent dissent have an incentive to use torture if the prisoner will not volunteer the information (Wantchekon and Healy 1999). Third, we suggest that the effect of voice is more likely than veto or freedom of expression to be palliative: when dissidents challenge the state with violence the people to whom an executive is responsible for retention of her office are unlikely to hold her accountable for "dirtying her hands" with torture to keep them safe (Walzer 2004). Fourth, unlike voice, institutions that contain veto points are populated with actors who have an incentive to challenge an executive who uses torture. Similarly, in states that guarantee freedom of expression people with an incentive to challenge the executive will also exist (i.e., reporters and activists). Put differently, there is an incentive compatibility between the executive and the median voter (or winning coalition members) with respect to torturing someone the executive believes is involved in violent dissent. However, veto points populated by partisans of another party or justices who desire independence from the executive, and reporters and human rights activists have an incentive incompatability vis-á-vis the executive who tortures suspected violent dissidents. We thus expect that while all three liberal democratic institutions will reduce the use of torture when the state is not challenged with violent dissent, we expect that effect to be strongly curtailed-especially for voice-when dissidents engage in violent protest or rebellion. Below we elaborate each claim and present testable hypotheses. 


\subsection{Hypotheses}

We begin with the conventional wisdom about regime type and torture that, as the shocked response to Abu Ghraib revealed, suggests that democratic states rarely resort to torture and certainly do so with far less frequency than autocratic states. The key to developing the nascent argument that likely underlies the conventional wisdom lies in laying bare the extent to which liberal democracies have institutions that [1] enhance participation such that the population can respond to moral and legal concerns about torture and threaten the executive who uses torture with removal via the ballot and/or [2] protect minorities by enabling other political actors outside the executive who have an incentive to challenge an executive who resorts to torture to do so. We follow Davenport (2007b) and suggest that two implicit causal mechanisms support the conventional wisdom: voice (an open and competitive political system with elections that provide politicians with an incentive to heed popular opinion) and veto (constraint on executive authority created by a dispersion of power). We further follow the lead of those who emphasize the important role of free speech in democracy (e.g., Mueller 1992, Van Belle 2000) and argue that the legal guarantee of freedom of expression enables the emergence of another group of actors who have an incentive to check executive power, thus giving the executive cause to think twice before (tacitly) approving the use of torture.

Gallie (1956) identified democracy as the most contested of political concepts, and we readily recognize the rocky shoals on which any given definition rests. We elide that debate to some extent by focusing less on democracy than on democratic institutions. That said, we embrace a conceptual definition that includes liberal democratic rather as well as classic democratic institutions. ${ }^{9}$ Many scholars prefer a definition of democracy that focuses attention exclusively on rule by the people (e.g., DeTocqueville 1835; Schumpeter 1962; and Dahl 1971). In our approach voice refers rule by the people and includes both the extent of suffrage in elections

\footnotetext{
${ }^{9}$ Other examples of definitions of democracy as liberal democracy include Collier and Levitsky (1997), Zakaria (1997) and Gates et al. (2006). Collier and Levitsky (1997) propose a procedural definition that adds civil liberties to Dahl's (1971) two dimensions of suffrage (participation) and contestation. Zakaria (1997) defines liberal democracies as those that hold free and fair elections, are governed by the rule of law, separate government power across different branches, and protect civil liberties and property. Gates et al. (2006) add executive constraints to Dahl's two dimensions. We lump Dahl's participation and contestation dimensions into voice. Our veto is similar to Gates, et. al's (2006) executive constraints. As we explain below we treat freedom of expression, which Collier and Levitsky include under civil liberties and Gates, et. al. do not consider, as a distinct characteristic that influences both voice and veto.
} 
and the absence of restrictions on the ability of politicians to enter the electoral arena and compete for office. Veto, on the other hand, identifies the extent to which actors other than the executive are able to exercise authority. It thus includes the extent to which an independent legislature and/or judiciary can check executive authority.

While previous work ion democracy and human rights violations has limited attention to those two characteristics of democratic regimes (e.g., Davenport and Armstrong 2004, Bueno de Mesquita et al. 2005, Davenport 2007b) we add a third characteristic that others conceive of as a distinct characteristic of democracy (e.g., Collier and Levitsky 1997, Zakaria 1997, Mueller 1992, Van Belle 2000): freedom of expression and alternative sources of information. We treat freedom of expression as a distinct characteristic of (liberal) democracies because free speech and press make it possible for activists and, especially, reporters to challenge or expose illegal executive activity.

To the extent that the conventional wisdom is correct one would expect to find that at least one of these three democratic institutions-voice, veto, or freedom of expression-would reduce the probability that an executive uses torture. That appears to be the type of expectation (implicitly) held by those who were shocked by the revelation of Abu Ghraib. We offer an alternative argument and suggest that while liberal democratic institutions may be associated with lower probabilities of torture, the extent to which they have such an impact will be strongly mediated by the presence of violent dissent. Put another way we are quite circumspect that liberal democratic institutions will substantially reduce the likelihood of torture when the state is challenged with acts of dissident violence. More specifically, we argue below that voice is unlikely to have any effect in the presence of violence, and that the negative effects of both veto and freedom of expression will be strongly diminished by the presence of violent dissident activity.

We begin our case by noting that a large body of studies have uniformly found that all governments respond to dissident violence with repression (see Davenport 2007a). When we combine that finding with the emphasis governments place on intelligence collection as a counterinsurgency tactic $^{10}$ we are led to conjecture that what holds for the broad class of repressive

\footnotetext{
${ }^{10}$ For example, see http://www2.gwu.edu/ nsarchiv/NSAEBB/NSAEBB122/ for a discussion of CIA training
} 
behavior will also hold for the more specific practice of torture. That said, Davenport (1995) found that not all forms of violent dissent affect government repression equally. That leads us to focus our attention on the most threatening forms of violence-acts of guerrilla war or a state of civil war-and anticipate that this type of violent dissent will dramatically raise the propensity of executives to authorize the use of torture.

Two arguments produce dramatic conclusions with respect to the incidence of torture when a state is threatened with violent dissent. First, Wantchekon and Healy (1999, 599) develop a game theoretic model that demonstrates that once a state concludes that a captive has information it could utilize to thwart attacks "torture takes place with probability 1.00." Their conclusion-that all states that have a utilitarian justification for using torture will end up doing so-is based on the incentives of the actors involved: a state, an interrogator, and a dissident. In their game the state believes that the dissident likely has information about the planned acts of guerrilla struggle or civil war. Questioning under the guidelines established by the human rights regime (i.e., the International Bill of Human Rights, the Geneva Conventions, and the Convention against Torture) often fails to yield useful information. In such a situation the state can either instruct the interrogator to use torture or it can accept that it cannot access the information it believes the suspected dissident has. Wantchekon and Healy (1999) show that because [1] the innocent person cannot divulge information and [2] the dissident has an incentive to hide the truth, the state always has a utilitarian incentive to employ torture because there is a chance that doing so will yield useful information ${ }^{11}$

Walzer (2004) and Levey (2007) argue that liberal democracy and torture can co-exist comfortably. ${ }^{12}$ They argue, in effect, that politicians in liberal democracies are agents hired by the voters to provide protection for the body politic. While voters in liberal democracies prefer to behave ethically, they also expect politicians to 'dirty their hands' when doing so is manuals from the 1960 s and 1980s.

${ }^{11}$ Among other things their model demonstrates that the interrogator need not be a sadist. In the model a professional interrogator who places obligation to duty over ethical concerns will follow orders to torture.

${ }^{12}$ These arguments implicitly assume that torture is effective for eliciting information or eliminating dissent. To our knowledge neither relationship has been examined systematically (Fein, Lehner and Vossekuil 2006). Individuals point to specific instances but they have not attempted to investigate the issue rigorously across space and time. Instead, our argument assumes that authorities believe it to be an important strategy for practical as well as symbolic reasons in countering specific types of contentious behavior. 
needed to provide adequate security. Politicians know this, and respond accordingly, but try to do so in secret because they cannot be certain whether the voters will approve of any given use of torture (i.e., agree that the threat to security warranted torture). As long as voters reject politicians who are too eager to 'dirty their hands' when such politicians fail to adequately deny and hide their behavior, democracy can function properly. ${ }^{13}$ Discussions of the 'ticking time bomb scenario' provide similar arguments (e.g., see Dershowtiz's (2002) discussion of 'torture warrants' and the discussion in Bowden (2003)). ${ }^{14}$

These arguments and the evidence on repressive responses to dissident violence lead us to question the conventional wisdom that liberal democratic institutions will always reduce the likelihood that a state turns to torture.

That said, while the literature reports that all states respond to dissident violence with repression, Davenport (1995) reports that nondemocratic states have a stronger repressive response than anocratic states, and anocratic states have a stronger repressive reaction than democratic states. In their studies of human rights behavior Davenport and Armstrong (2004) and Bueno de Mesquita et al. (2005) find that regime type has an essentially binary effect: only highly democratic institutions systematically violate fewer of their citizens' human rights. Yet none of those studies, the other work we have reviewed, nor Hathaway's study, has considered the possibility that Wantchekon and Healy (1999) are right when they contend that all states facing a dissident threat will act on their incentive to employ torture. We rely upon both the Wantchekon \& Healy model and the "dirty hands" argument to produce our first hypothesis:

Hypothesis 1: The probability that a state uses torture is, within measurement error, one when the dissidents use violent action to challenge the state, but less than one in the absence of violent threats to state rule.

We can express hypothesis one more formally as: $p(T \mid \sim V D)<p(T \mid V D) \approx 1$, where $T$ rep-

\footnotetext{
${ }^{13}$ This argument has interesting implications for democratic performance, a point to which we return in the conclusion.

${ }^{14}$ Democratic states often justify the use of "coercive interrogation" as a necessary response to particularly elusive challenges-forms of dissent, which are unconventional in their approaches (e.g., using "hit and run" tactics, relying upon avoidance of authorities until conflict occurs) and that are not believed to be well countered with other strategies of repression. This was particularly true with respect to the Bush Administration's policy toward the interrogation of enemy combatants in Guantanamo Bay, which then spread to other US detention centers such as Abu Ghraib (Hersh 2004, Mayer 2006, Hersh 2007).
} 
resents the use of torture, $V D$ indicates violent dissident activity, and the $\sim$ symbol represents "not."

Having presented the first hypothesis, note the following tension in the arguments we have advanced thus far. First, the empirical work on states' repressive responses to threats, Wantchekon \& Healy's (1999) game theoretic model, Walzer's (2004) and Levey's (2007) arguments about "dirty hands," and the counterinsurgent literature all suggest that states will respond to violent threats with torture. Yet second, the argument above suggests that at least one, and perhaps all three, institutional characteristics of democracies-voice, veto, and freedom of expression-will inhibit the executive's use of torture. Are these palliative institutions that operate effectively only in the absence of a violent dissident threat, or are they closer to a panacea that effectively constrains executives from violating human rights despite the utilitarian incentive to do so? We present two reasons to believe that while veto and freedom of expression will provide some constraint on executives in liberal democracies challenged with violent dissent, voice is considerably less likely to do so.

First, if we assume that [a] the executive, and [b] veto players in other branches of government and/or the median voter (or winning coalition member) have different preferences across the issue of human rights versus the instrumental value of torture, and [c] the press has professional, ethical, or pecuniary incentives to investigate allegations of torture, then we would expect liberal democratic institutions to make a difference. ${ }^{15}$

Yet, is there reason to believe that the torture preferences of the median voter (or winning coalition member) will diverge from a democratically elected executive when the state is faced with violent dissent? We take a pessimistic view and suggest that this is not likely. A representative mechanism motivates our expectation. We conjecture that the (relative) openness of the political system in countries with democratic institutions will tend strongly to produce the outcome that only groups that have little, if any, effective representation will resort to violent

\footnotetext{
${ }^{15}$ We need not assume that veto players necessarily have different policy preferences from the executive. If the median voter (or winning coalition member) has a preference with respect to the use of torture that differs from the executive, then the veto players who desire to displace or replace the executive have an incentive to punish an executive who breaks the law by using torture (recall that torture is illegal in international and virtually all national law). The executive knows this and will take it into account when deciding whether to (implicitly) order the use of torture.
} 
tactics to press their claims about changes in policy. Further, if this view is shared by other actors in democratic polities it will undermine the legitimacy of the use of violence to achieve political ends. As such, the median voter (much less the winning coalition member) is unlikely to punish an executive ruling a democratic polity who (tacitly) orders torture against suspected dissidents in the government's control when those dissidents have used violence to advance their claims. ${ }^{16}$

Second, these processes are reinforced by the more philosophical arguments advanced by Foucault (1979) and Walzer (2004). Foucault argues that people want the state to protect them without having to acknowledge that fact. [CD: Please revise/amplify] As noted above, Walzer makes a similar, though distinct, argument that the public wants executives who will "dirty their hands" to protect the body-politic, but ethical and moral considerations entice the public to (desire to) punish executives who get caught with "dirty hands." Walzer thus concludes that executives realize that publics tacitly expect them to use torture, but expect them to do so secretly and issue public denials.

Third, though studies by Davenport (1998), Davenport and Armstrong (2004), and Bueno de Mesquita et al. (2005) find that elections are associated with lower levels of repression, Davenport (1997) finds that elections only reduce repression in autocratic countries, and Richards (1999) reports that elections have no effect on the likelihood that a state uses repression. The positive results notwithstanding, when we combine the arguments listed above with the negative findings reported by Davenport (1997) and Richards (1999), we are led to expect voice to be ineffective when the state is faced with violent dissent. Dissidents who use violence are unlikely to be voters (much less winning coalition members), and thus-given their use of violence-are unlikely to receive widespread public support. Further, executives are likely to believe that the voters (and especially the winning coalition members) expect them to use torture when "necessary." Both of these arguments suggest that the executive and the median voter (and winning coalition member) have largely compatible incentives when it comes to security and torture.

\footnotetext{
${ }^{16}$ One can build upon the theoretical results of Bueno de Mesquita et al. (2003) to extend this argument to states with autocratic regimes. Their selectorate theory implies that states with autocratic institutions will have small selectorates (and even smaller winning coalitions), and it is difficult to imagine members of the winning coalition pressuring the executive not to torture dissidents who are using violence.
} 
We therefore offer the following:

Hypothesis 2: When states are confronted with violent acts of political dissent, voice will lose its effectiveness at reducing the probability that the state uses torture.

We can express hypothesis two more explicitly in two parts.

2a: $p(T \mid V c, \sim V D) \ll p(T \mid \sim V c, \sim V D)$

2b: $p(T \mid V c, V D) \simeq p(T \mid \sim V c, V D)$

where $V c$ represents voice, the $\ll$ symbol indicates considerably less than, and the other terms are as defined above.

What of veto? Here, our proposed mechanism is different: unlike the executive and the median voter (or member of the winning coalition), the executive and veto players have different incentives. While our argument about the ineffectiveness of voice depends on the policy preferences of the median voter and the perceived legitimacy of the tactics of those demanding a change in policy, we invite the reader to consider that the exercise of veto will be a function of [1] constituent representation and/or [2] careerism. That is, an actor in a position to exercise veto would need to be motivated to do so because she represented a constituency who is opposed to the executive's behavior or, even in the absence of such a constituency, believes that she might be able to advance her career interests by challenging the executive. Our argument about the likely ineffectiveness of voice limits the likeliness that the first mechanism operates, though the second is still available, and we suggest that while it will operate, it will do so with only limited impact when the state is challenged with violent dissent. ${ }^{17}$ Specifically, we anticipate that only partisans who are not members of the executive's party will respond to the careerism incentive. For example, independent courts will have an incentive to retain their independence (should they have any), and politicians outside the executive's party have an incentive to either

\footnotetext{
${ }^{17}$ We argue above that the median voter is unlikely to be sympathetic to victims of torture. Politicians who wish to displace the executive will thus make their charges on moral and legal grounds whereas the executive will either deny the charges or defend her behavior on utilitarian grounds, emphasizing the evil goals of the dissidents and their violent activities. Judges will make their case on legal grounds, likely buttressed by moral claims. Which of these actors mounts the more effective media campaign is outside the bounds of our study. Our argument merely requires that veto players from other parties, or the judiciary, have an incentive to persuade the median voter that the executive should not have used torture and that the executive believe that there is some chance that such efforts will persuade the median voter to sanction the executive. The more veto players there are in a polity, the more wary the executive should be about adopting a policy that would lead her to need to wage such a public relations campaign.
} 
weaken, or perhaps displace the executive. The executive should anticipate that the greater the levels of separation of power and/or number of veto players in a polity the greater will be the likelihood that one of them will expose the executive's (implicit) sanction of torture. This recognition should lessen the likelihood that the executive will respond to the strong incentive to (implicitly) approve torture when dissidents use violence.

Hypothesis 3: When states are confronted with violent acts of political dissent the effectiveness of veto will be considerably reduced.

Hypothesis three can be presented more formally as

3a: $p(T \mid V t, \sim V D) \ll p(T \mid \sim V t, \sim V D)$

3b: $p(T \mid V t, V D)<p(T \mid \sim V t, V D)$

where $V t$ represents veto, and the other terms are as defined above.

Finally, freedom of expression produces a group of actors whose incentives are incompatible with an executive who is breaking the law. That human rights activists have goals at odds with an executive using torture is readily apparent. Mueller (1992) argues that the greater the freedom of expression in a polity the greater the ability to petition (or lobby). Activist groups-in our case, human rights and legal activists-will have a greater impact on public policy the greater the freedom of expression.

Turning to the press we assume that news reporters and editors respond to the dictum that "if it bleeds it leads." We further assume that torture both disgusts and titillates, and that scandal sells. Thus ambitious reporters and editors working in a polity with freedom of expression have a career incentive to uncover, and report, stories of an executive's (implicit) sanction of torture. Activists further have an incentive to make charges to reporters. Thus, the greater the freedom of expression protections in a polity, the more we expect activists and the press to challenge executives that overstep legal boundaries. ${ }^{18}$

\footnotetext{
${ }^{18}$ As noted above, that the median voter is unlikely to be sympathetic to victims of torture does not undermine our argument. Because the size of the audience is likely to be a positive function of the sensational aspects of the story, many (and, we submit, the modal) reporters and editors will look to interview activists who will make emotional appeals to ethics, norms, and the law. Again, whether the executive is able to win a public relations battle in the face of such reports is immaterial to our argument. We merely require that the executive believe that she might lose, and act accordingly. In such a circumstance she will take that into account, and thus will be increasingly less likely to use torture the greater the protections of freedom of expression in the polity over which she rules.
} 
We suggest that the outcome of activists and the press being more likely to publicly challenge an executive of a state that protects freedom of expression is that executives in such states will be less likely to (tacitly) endorse torture for doing so might trigger public attacks that could threaten their tenure in office. Nevertheless, we return to the arguments of Wantchekon and Healy (1999) and Walzer (2004) and observe that when the state is threatened with violent dissident activity, the executive has a strong incentive to (tacitly) authorize torture of captured suspected dissidents. Yet, while all executives will have an incentive to torture a suspected dissident in the security forces control, executives in states with freedom of expression guarantees will be less likely to act on that incentive than executives in states with fewer or no such guarantees. This discussion leads us to offer the following hypothesis.

Hypothesis 4: When states are confronted with violent acts of political dissent the negative impact of a free press on the likelihood of torture will be considerably reduced.

Like the preceding two hypotheses, hypothesis four can be expressed more explicitly as follows: 4a: $p(T \mid F A, \sim V D) \ll p(T \mid \sim F A, \sim V D)$ 4b: $p(T \mid F A, V D)<p(T \mid \sim F A, V D)$ where $F A$ represents freedom of expression, and the other terms are as defined above.

If our arguments are on target, they not only solve the puzzle of Abu Ghraib, but also illuminate what may prove to be one of the biggest weaknesses in the domestic democratic peace. The interactive influence identified here is crucial to the current discussion because it reveals the potential fragility of the domestic democratic peace. For instance, if liberal democratic institutions only diminish repression in certain circumstances, then this is an important finding for academic research, public policy, and advocacy. Moreover, the democracy-violent dissent interaction is consistent with broader discussions about socio-political control within modern, democratic societies which emphasize the importance of reducing public scrutiny of government coercive action while simultaneously allowing authorities to pursue political order (e.g., Donner 1980). This last point is particularly interesting for it suggests that liberal democratic institutions do not eliminate state repression; they merely change its form. Discussions of this transformation tend to focus on non-violent techniques like electronic surveillance (e.g., Gid- 
dens 1987), but the same argument can be applied to torture as well (e.g., Rejali 1994, Einolf 2007). To summarize, while democratic institutions likely depress an executive's incentive to use torture, that effect is likely palliative when the state is threatened with violence. Further, we suspect that voice is even less likely than veto or freedom of expression to have an impact during periods of armed protest and rebellion.

\section{Research Design, Data and Methodology}

Because our argument focuses on a comparison between states with democratic and autocratic institutions we need a sample with substantial variation across those institutions. We also require variation in both violent activity targeting the state (i.e., violent dissent) and state uses of torture. A cross-national sample is most appropriate, and though we do not restrict our hypotheses to the final quarter of the 20th Century, data availability limits our attention to that time frame. Our unit of observation, then, is the country-year, and we have a pooled cross-sectional time-series data structure. Below we discuss the estimation issues that arise.

Our research design has an important bias issue: our measure of torture is a biased under count of torture events. This is not our choice; under counts are inevitable in any empirical measure of an event that conspirators wish to hide from public view. Importantly, this bias is not a serious problem for our research design. As King, Keohane and Verba (1994, 130) explain, truncation in the dependent variable produces biased inferences of the size of the effect of any independent variable on that dependent variable. In other words, our study will underestimate the substantive effect of regime type and threat on torture. More specifically, given that we develop a dichotomous indicator of torture (see below) our measure will misclassify states that successfully hide their use of torture as states that did not use torture. This type of measurement error is biased against our hypothesis and is thus the conservative sort of bias that one wants if one's design or measures must contain bias. ${ }^{19}$

\footnotetext{
${ }^{19}$ At a recent meeting Håvard Hegre expressed his belief that these data suffer from another, more tenacious, form of measurement error that we will call conditional bias: the extent to which the data have a downward bias is not constant across press freedom. Bollen (1992, 200) and Goodman and Jinks (2003, 175-6) assert that this is a serious problem in all human rights performance data, and Drakos and Gofas (2006) produce evidence to support the claim that the same measurement bias exists with respect to data that record the number of acts of terror (i.e., states that ensure freedom of the press will have systematically less under-reporting of terror
} 


\subsection{Measuring Torture}

To measure our dependent variable, we use data from the Cingranelli and Richards (CIRI) Human Rights database which codes the State Department and Amnesty International country reports in 146 countries from 1980 to $1999 .{ }^{20}$ The CIRI project defines torture as

the purposeful inflicting of extreme pain, whether mental or physical, by government officials or by private individuals at the instigation of government officials. Torture includes the use of physical and other force by police and prison guards that is cruel, inhuman, or degrading. Torture can be anything from simple beatings, to other practices such as rape or administering shock or electrocution as a means of getting information, or a forced confession (Cingranelli and Richards 2004a, 12).

It thus includes acts of "dirty torture," "clean torture," and "torture lite," and is thus a valid indicator for our study. The CIRI project codes an ordinal variable based on the number of torture events reported in a given country-year, thus producing an under count of the real number. As noted above this bias works against finding support for our hypothesis and is thus conservative. The original indicator is a trichotomous measure of the number of incidents (with one and 50 as the two thresholds). We collapse the two non-zero values to create a binary indicator scored one when there is at least one reported case of torture in a given country-year and zero when there are none.

events than states that restrict the press). Interestingly, Li (2005) argues that-with respect to acts of terror-the conventional wisdom is misplaced, and produces statistical results consistent with his expectations. Leaving the measurement bias in the terror data aside, measurement bias in our project this suggests that we have a systematic over-reporting of zeros (no torture) in countries that restrict the press. This is a different type of bias and requires a solution. We are unaware of work that reports and addresses this issue, and have set out to write a zero-inflated logit model. Zero-inflated models for event counts are well developed, but we are unfamiliar with efforts to extend this type of model to a logit setting. One of the authors of this study has recently developed, with others, an alpha version of such an estimator. Should we successfully develop this estimator, a future version of this study will report the results obtained when one uses that estimator. We should also note that Hathaway and Ho (2004) use a Bayesian factor analytic approach as a solution to generic measurement error (as opposed to the specific measurement bias considered here).

${ }^{20}$ This is available from http://www.humanrightsdata.com/. Significantly deviating from earlier efforts to measure physical integrity rights, which combined distinct strategies of repression (e.g., Cingranelli and Richards 1999a, Henderson 1991, Mitchell and McCormick 1988, Poe and Tate 1994), CIRI is an important project because it disaggregates human rights violations, individually identifying torture, extra-judicial killings, disappearance, political imprisonment, freedom of speech and press, freedom of religion, freedom of movement, freedom of assembly and association, political participation, worker's rights, women's political rights as well as women's economic and social rights (Cingranelli and Richards 2004b). 
We selected CIRI rather than the Hathaway (2002) data for several reasons. First, Hathaway uses only U.S. State Department reports, which Poe et al. (2001) suggest has a particular bias. Cingranelli and Richards (2004b) use both the State Department and Amnesty International data to code countries on human rights practices. Second, the Hathaway measure includes fewer countries (likely as a function of using the State Department Country Report). In particular, one of the countries excluded from Hathaway's sample is the United States. Though this is not necessarily a fatal flaw, the fact that the behavior of the United States is motivating this investigation requires us to take lengths to ensure the U.S. is in the sample. Finally, the Hathaway sample includes fewer years (she starts at 1985 and CIRI starts at 1980). We prefer to leverage all of the data possible to test our argument.

\subsection{Empirical Measures of Democratic Institutions}

A sizeable number of empirical measures of democratic institutions has become available in recent years, and as such we have a number of potential operational indicators for our voice, veto, and freedom of expression concepts. Table 1 identifies the variables we use to measure each concept.

A proper discussion of these indicators exceeds the space available for an article, so we have moved that discussion to an Appendix that we will make available online with publication, but for the present is attached as part of this document. Three of the variables require clarification here. The ACLP binary measure of democracy comes from the updated version in Cheibub and Gandhi (2004) We reversed the scale so that 0 is an autocratic polity and 1 is a democracy. CIRI's Speech Restriction variable we reversed the scale such that it still ranges from 1-3, but one is now severe restrictions and three is no restrictions. For Van Belle's Media Restriction indicator we collapsed the scale to a binary indicator where a value of one indicates a free press.

\subsection{Violent Dissent and other Exogenous Variables}

To examine our hypotheses we also need to operationalize violent political dissent. To do so we use two different sources. First, we use data on civil war coded by the Correlates of War Project (Sarkees 2000, Singer and Small 1972). Second, we use a dichotomous variable signifying 
Table 1: Operational Indicators for Voice, Veto and Freedom of Expression

\begin{tabular}{|c|c|c|c|}
\hline Concept & Source & Variable & Range \\
\hline \multirow[t]{8}{*}{ Voice } & Alvarez et al. (1996) & aclpreg & $0-1$ \\
\hline & Bernhard, Nordstrom and Reenock (2001) & democracy & $0-1$ \\
\hline & Polyarchy Index (Vanhanen 2000b) & PolyDemoc & $0-47$ \\
\hline & Gates et al. (2006) Polyarchy Recoding & logpartcomp & $0-4.3$ \\
\hline & $\begin{array}{l}\text { Polity's Openness of Executive Recruitment } \\
\text { (Marshall and Jaggers 2001) }\end{array}$ & xropen & $0-4$ \\
\hline & Polity's Competitiveness of Executive & xrcomp & $0-3$ \\
\hline & Recruitment (Marshall and Jaggers 2001) & & \\
\hline & $\begin{array}{l}\text { Polity's Competitiveness of Participation } \\
\text { (Marshall and Jaggers 2001) }\end{array}$ & parcomp & $0-5$ \\
\hline \multirow[t]{8}{*}{ Veto } & Veto Points (Keefer 2005) & checks & $1-18$ \\
\hline & Judicial Independence (Political Risk Group nd) & $\mathrm{J}$ & $0-1$ \\
\hline & Law \& Order (Political Risk Group nd) & Law_-_Order & $2-6$ \\
\hline & Legislative Veto Points (Henisz 2002) & PolConIII & $0-0.893$ \\
\hline & sub-Federal Veto (Henisz 2002) & $\mathrm{F}$ & $0-1$ \\
\hline & Legislative/Judicial/sub-Federal Veto & PolConV & $0-0.893$ \\
\hline & Points (Henisz 2002) & & \\
\hline & $\begin{array}{l}\text { Polity's Executive Constraints } \\
\text { (Marshall and Jaggers 2001) }\end{array}$ & xconst & $0-7$ \\
\hline \multirow{2}{*}{$\begin{array}{l}\text { Freedom } \\
\text { of Expression }\end{array}$} & Speech Restriction (Cingranelli and Richards 2004b) & speech & $1-3$ \\
\hline & Media Restriction (Van Belle 2000) & fpressd2 & $0-1$ \\
\hline
\end{tabular}


the presence of guerrilla war in any given country-year taken from the Cross-National TimeSeries Data Archive (Banks 2001). Since these events are relatively rare, and in this context providing estimates with any precision would be difficult, we create a variable we name violent dissent that is a dichotomous variable coded 1 when either of the violent conflict measures identified above exist and 0 when neither is present. We thus have a binary measure of violent dissent, and we multiply voice, veto, and free speech, respectively, by this measure to create the variables that are used to evaluate our three hypotheses.

We also include two control variables that have been found to effect the use of repressive strategies in a broad range of empirical studies: GDP per capita and Population ${ }^{21}$ and are also known to co-vary with our other variables of interest. ${ }^{22}$ To measure these variables we use the replication data from Fearon and Laitin (2003).

\subsection{Statistical Methodology}

Building on the advice of Beck et al. (2002), we use a dynamic logit model. The dynamic modifier suggests that the logit incorporates temporal dynamics. We use this model for both substantive and statistical reasons. First, we are interested in how violent challenges make governments change their repressive strategy with respect to torture. This model allows us to investigate the probability that an executive (implicitly) endorses torture across two contexts: when it has not been (implicitly) endorsing torture, and when it has already been (implicitly) endorsing torture. Second, this type of analysis has been suggested by Beck et al. (2002) as a reasonable way to deal with discrete pooled time-series cross-section data. We now present our empirical results.

\footnotetext{
${ }^{21}$ Sambanis $(2004,822)$ argues that population is likely robust in studies of civil war onset because studies do not normalize deaths by population (i.e., use a 'per capita deaths' threshold rather than 'deaths' threshold). Given that we use a binary measure based on a count of torture events rather than torture events per capita, we include population in our study.

${ }^{22}$ While "we can omit a control variable if... [t] he omitted variable is uncorrelated with the included variable," we must control for variables we know to be correlated with our primary variables of interest (King, Keohane and Verba 1994, 170). See, also, Ray (2003, 13-15). A number of studies have shown that both regime type and the presence of violent dissent are associated with per capita national income and population.
} 


\section{Findings}

We begin with some descriptives. Cingranelli and Richards $(1999 a, 411)$ report that in the final twenty years of the twentieth century states respected the physical integrity right of freedom from torture less than any other such right. We use those data, and in our study torture is depressingly common: between 1981 and 199979 percent of the country-years exhibited at least one reported case of torture. Moving to bi-variate relationships, we established the plausibility of our hypotheses by first examining the joint distribution of torture with each of our independent variables using cross-tabular contingency tables. We do not report those results here, ${ }^{23}$ except to note that when a state was faced with at least one act of violent dissent the observed frequency of torture is $0.97 .{ }^{24}$ While that is not quite the 1.0 value predicted by Wantchekon and Healy (1999), it is important to reiterate that this is almost surely an under count (i.e., some countries in some years likely were successful hiding their use of torture), and for practical intents and purposes can be treated as consistent with their expectation. We thus interpret it as bi-variate evidence consistent with hypothesis one.

Next, consider the transition matrix in Table 2. Whether the state used torture in the year prior to any given year has a substantial impact. 93 percent of the states that tortured in the previous year continue to torture in any given year, yet 33 percent of those states that did not torture in the preceeding year use torture in any given year. These figures underscore the point highlighted by Cingranelli and Richards (1999a): torture is not only common, but states that use it have a very strong tendency to keep using it. Further, states that did not use it have a non-trivial probability of using it in the following year. This matrix also foreshadows a finding we report below: when a state used torture last year there is rather limited variation to explain in the probability that it uses torture this year.

A second transition matrix, reported in Table 3, reproduces the transition matrix conditioned on the absence/presence of violent dissent. A handful of points are worth highlighting. First, we see that the transition to/from torture is effectively the same in the absence of violent dissent as

\footnotetext{
${ }^{23}$ Earlier versions of this paper that were reported at professional meetings contain some of those results, and all of them can be reproduced using a replication data set that we plan to make available upon publication of this study.

${ }^{24}$ In the absence of violent dissent the relative frequency of torture during this period is 0.72 .
} 
Table 2: Transition Matrix for Torture, 1981-1999

\begin{tabular}{ccc}
\hline & No Torture $_{t}$ & Torture $_{t}$ \\
No Torture \\
t-1 & 418 & 208 \\
row $\%$ & $67 \%$ & $33 \%$ \\
Torture $_{t-1}$ & 160 & 2,170 \\
row $\%$ & $7 \%$ & $93 \%$ \\
\hline
\end{tabular}

Table 3: Conditional Transition Matrix for Torture, 1981-1999

\begin{tabular}{|c|c|c|c|c|}
\hline & \multicolumn{2}{|c|}{ No Viol Diss } & \multicolumn{2}{|c|}{ Viol Diss } \\
\hline & No $_{\text {Torture }}$ & Torture $_{t}$ & No $_{\text {Torture }}$ & Torture $_{t}$ \\
\hline No $_{\text {Torture }}{ }_{t-1}$ & 412 & 192 & 6 & 16 \\
\hline row $\%$ |Viol Diss & $68 \%$ & $32 \%$ & $27 \%$ & $73 \%$ \\
\hline Torture $_{t-1}$ & 153 & 1,620 & 7 & 550 \\
\hline row $\%$ |Viol Diss & $9 \%$ & $91 \%$ & $1 \%$ & $99 \%$ \\
\hline
\end{tabular}

it is in Table 2. That is because violent dissent is relatively uncommon: Of the 2,956 countryyears represented in each table, only 579-or 20 percent-experienced violent dissent. Second, the transition pattern is radically different in the presence of violent dissent: 73 percent of those country-years that did not use torture in the preceding year use it in the current year, and 99 percent of those that used it in the prior year continue to use it. Put another way, given violent dissent states that were not using torture are very likely to begin using it and those that have been will almost certainly continue. This is broadly consistent with hypothesis one. It also suggests that because we control for both the use of torture in the preceding year and the absence/presence of violent dissent in our statistical models below when both past torture and violent dissent are present there is very limited variance to explain.

\subsection{Statistical Model}

Turning our attention to the multivariate model, we estimate parameters for a dynamic logit model (Beck et al. 2002) and calculate robust standard errors by clustering on country. To use a dynamic logit one estimates two equations separately, each conditioned on the lagged value of the dependent variable. In our case we estimated one equation for those cases where there was no torture in the preceding year, and another for those cases where there was torture in the 
previous year. The estimated effects are thus conditional (i.e., the log-odds of observing torture given a change in the independent variable given that we observed (or did not observe) torture in the preceding year), and we report two results for each independent variable.

The parameter estimates from a logit model are not directly interpretable and, as is well known, the effects are not constant over different values of the other independent variables (King 1989, Long 1997). As such, there is a wide variety of quantities of interest one might report to communicate the substantive effects. To keep the interpretation of our results manageable we focus on the magnitude of the impacts of our independent variables on the likelihood that a state used torture, and the statistical significance of those effects, across three settings:

- Torture Averse State: ${ }^{25}$ we set the independent variables of interest such that the likelihood of torture is as small as possible. ${ }^{26}$

- Typical state: we set the independent variables of interest at their median (for discrete variables) or mean (for continuous variables) values. ${ }^{27}$

- Torture Prone state: we set the independent variables of interest such that the likelihood of torture is as large as possible. ${ }^{28}$

The fact that we have multiple interaction terms adds a final wrinkle of complexity to our interpretation. Fortunately, one can use Clarify (Tomz, Wittenberg and King 2003) and the techniques described in (Braumoeller 2004, Brambor, Clark and Golder 2006) to simulate the quantities of interest, including those for the interaction terms. We used Clarify and our own code to simulate 100,000 iterations and then calculated the predicted probabilities for

\footnotetext{
${ }^{25}$ Our torture averse state does not exist in our dataset and thus is an example of what King and Zeng (2006, $2007 b$ ) refer to as an 'extreme counterfactual,' which is to say a counter factual instance that does not exist in the dataset. There is debate about whether the King and Zeng concern is well placed (e.g., Sambanis and Doyle 2007, Schrodt 2007, King and Zeng 2007a), and we do not take a strong position here. Instead, we observe that the torture averse state does not exist in our data. This is, perhaps, most important when there is violent dissent, and we revisit this issue when discussing results below.

${ }^{26}$ Specifically, this is a country with elections, a veto score of 0.89 , a fully free press, and no violent dissent (control variables-logged population and logged GDP/capita-are set to their mean).

${ }^{27}$ Specifically, this is a country without elections, a veto score of 0.34 , a somewhat free press, and no violent dissent (control variables-logged population and logged GDP/capita-are set to their mean).

${ }^{28}$ Specifically, this is a country without elections, a veto score of 0 , no free press, and violent dissent (control variables-logged population and logged GDP/capita-are set to their mean).
} 
given changes in our independent variables. ${ }^{29}$ We also used Scott Long's SPost command to produce marginal effects for the two control variables. Given the number of interaction terms the coefficient estimates do not provide much information. Further, since there are 13 models, each of which is estimated twice (once for when there was torture in the preceding year, and a second time when there was not), we produced 26 sets of estimates and related model statistics. The simulated substantive effects produce a large volume of additional output for each of the equations. Rather than try to present that material in an Appendix we will make all of it available in a replication dataset upon publication. Here we first summarize all of the findings and then present the simulated results for the variables that produced a statistically significant effect.

Recent work reports that the relationship between democratic institutions and repression is not linear: only states with high scores on various measures of democratic institutions exhibit lower levels of rights violations (Davenport and Armstrong 2004, Bueno de Mesquita et al. 2005, Davenport 2007b). As Davenport and Armstrong (2004, 551) state,

(b)elow certain values, the level of democracy has no discernable impact on human rights violations, but after a threshold has been passed (varying in accordance to which measure one is considering), democracy decreases state repression.

To explore whether the effects of voice and freedom of expression operate only at high levels is trivial given our binary and trichotomous operational indicators of those concepts: we simply examine the maximum value. Veto is another matter. To explore whether it only has an influence at high levels we calculated the impact of changing the values across its range.

\subsection{Overview}

Table 4 reports a summary of the findings. The rows represent the independent variable of interest and the cell entries represent the sign of any statistically significant marginal effects found across the three baseline states (torture averse, typical, and torture prone). ${ }^{30} \mathrm{~A}$ dash in

\footnotetext{
${ }^{29}$ Because of the interaction terms it was necessary to calculate the change in value for each interaction and include those value changes in the Clarify runs. The files needed to reproduce these results will be made available in a replication dataset we will post once the study has been accepted for publication.

${ }^{30}$ None of the signs of the quantities of interest reverse direction over the range of the independent variables.
} 
the cell indicates that we could not reject the null hypothesis of no impact on the probability of torture.

Table 4: Summary of Results

\begin{tabular}{lcccc}
\hline & \multicolumn{2}{c}{ Torture $_{t-1}=0$} & \multicolumn{2}{c}{ Torture $_{t-1}=1$} \\
& No Threat & Threat & No Threat & Threat \\
Voice & & & & \\
ACLP Regime & - & - & - & - \\
BNR Democ & - & - & - & - \\
Polyarchy & - & - & Neg & - \\
Gates, et al. & - & Neg & - & - \\
ParComp & - & - & - & - \\
XrComp & - & - & - & - \\
XrOpen & - & - & - & - \\
Veto & & & & \\
PolConIII & - & - & - & - \\
PolConV & - & Neg & - & - \\
J & - & - & - & - \\
F & - & - & - & - \\
Checks & - & - & - & - \\
Law \& Order & Neg & - & Neg & - \\
Xconst & - & - & - & - \\
Press/Speech & & & & - \\
CIRI Speech & Neg & - & - & - \\
Free Press & Neg & - & Neg & - \\
\hline
\end{tabular}

The first impression we take from this Table 4 is that only a few of the indicators of democratic institutions have an impact on the probability that a state uses torture. This is especially true, as foreshadowed by the transition matrices in Table 3, when the state used torture in the preceding year and the state is faced with violent dissent: none of the variables registers an effect in such a circumstance. Further, when dissidents engage in at least one act of violence only two of the variables (Gates, et al's indicator of Polyarchy and PolConV) have a statistically significant effect on the probability that the state uses torture. Four other variables (CIRI Speech, Van Belle's Free Press, VanHanen's Polyarchy, and ICRG's Law \& Order) have an impact, but only in the absence of a violent threat. 


\subsection{Voice}

We have seven operational measures of Voice, and two of them produce a statistically significant impact on the probability that the state uses torture. Four of the variables measure both the competition and participation dimensions that Dahl (1971) uses to define classical democracy: Vanhanen's Polyarchy index, Gates, et al's revised Polyarchy index, ACLP's regime indicator, and Bernhard, et al's Democracy variable. The first two variables are continuous over the intervals $0-47$ and $0-4.3$, respectively, and the other two are binary. Neither binary measure registers an effect on the likelihood that the state uses torture, but both of the continuous variables do, though only in some circumstances.

Hypothesis two states that Voice will not have an effect on the probability that a state uses torture when dissidents engage in violence, and that we do not expect it to have much of an impact-relative to Veto or Freedom of Expression-in the absence of violent dissent. More explicitly, hypothesis 2 a fails to receive support in 13 of the 14 opportunities. VanHanen's Polyarchy variable is the only measure of Voice that leads to a substantial decrease in the probability that a state uses torture in the absence of violent dissent. The other six measures of voice fail to produce a statistically significant impact on the the probability of torture given the absence of violent dissent, and VanHanen's measure only has an impact when the state used torture in the previous year.

Table 5: Change in Predicted Probability Given Percentile Change in Polyarchy

\begin{tabular}{lcccc}
\hline \hline \multicolumn{5}{l}{ Absence of Violent Dissent, Presence of Torture $t-1$} \\
Baseline & 0 to 50 th & 50 th to 75 th & 75 th to 90 th & 90th to max \\
\hline Averse & $-0.006 *$ & $-0.02 *$ & $-0.02 *$ & $-0.04 *$ \\
{$[0.90]$} & $(-0.02,-0.0001)$ & $(-0.07,-0.0004)$ & $(-0.08,-0.0005)$ & $(-0.13,-0.0009)$ \\
Typical & $-0.006 *$ & $-0.02 *$ & $-0.03 *$ & $-0.05 *$ \\
{$[0.94]$} & $(-0.01,-0.0003)$ & $(-0.04,-0.0007)$ & $(-0.06,-0.0007)$ & $(-0.14,-0.001)$ \\
Prone & $-0.006 *$ & $-0.02 *$ & $-0.02 *$ & $-0.05 *$ \\
{$[0.95]$} & $(-0.01,-0.0002)$ & $(-0.05,-0.0005)$ & $(-0.07,-0.0004)$ & $(-0.15,-0.0007)$ \\
\hline \hline
\end{tabular}

Table 5 and Figure 1 both display the change in the predicted probability given a change in the percentile of the distribution assigned to the value of VanHanen's Polyarchy variable given 
the absence of violent dissent and the presence of torture the year prior. The table reports the results over all three baseline settings for the other independent variables-a torture averse set of values, a typical set, and a torture prone set-the figure reports only the typical baseline. Increasing the value of Polyarchy reduces the probability of torture across all three settings. We also report, in square brackets, the predicted probability for each baseline given a value of zero for Polyarchy. When there is violent dissent and the state used torture in the preceding year the predicted probability ranges from 0.90 to 0.95 . The entries in the cells indicate that the impact of Polyarchy increases as one approaches the maximum value in the dataset. Further, the impact of Polyarchy on the likelihood of torture is effectively the same across all three settings: a change to the maximum value reduces the probability to a range of 0.81 to 0.85 , depending on the baseline values of the other variables.

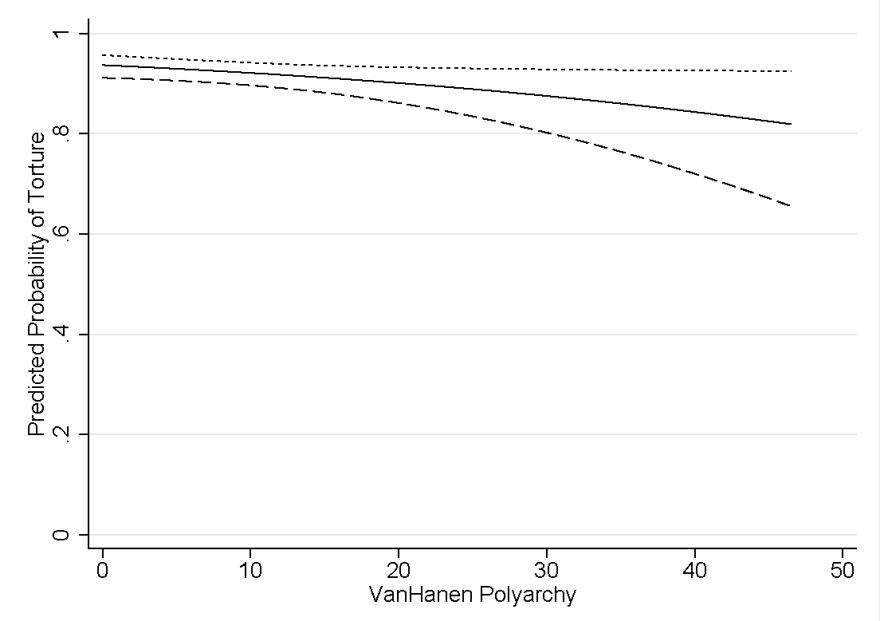

Consistent with hypothesis 2a, this is a fairly sizeable effect (given the baseline rate). That the size of the effect grows every time we move up the percentile suggests that the intersection of participation and a competitive party have a greater impact on reducing the continued use of torture than either alone.

Interestingly, hypothesis $2 \mathrm{~b}$ is supported across 13 of the 14 opportunities in which it was tested, but the one estimate inconsistent with $2 \mathrm{~b}$ uses a non-linear measure of Polyarchy (a point to which we return below). Table 6 shows that the Gates, et al. recoding of the Polyarchy measure has a large effect in the presence of violent dissent, though only when the state did not 
use torture in the preceding year. This result is inconsistent with hypothesis $2 \mathrm{~b}$ which expected little, if any, relationship.

Table 6: Change in Predicted Probability Given Percentile Change in Gates, et al.

\begin{tabular}{lccccc}
\hline \hline \multicolumn{7}{l}{ Threat, No Torture $t-1$} & & & & \\
& & & & & \\
Baseline & 0 to 25 th & 25th to 50 th & 50 th to 75 th & 75 th to 90 th & 90 th to max \\
\hline Averse & $-0.13 *$ & $-0.21 *$ & $-0.08 *$ & $-0.04 *$ & $-0.04 *$ \\
{$[0.88]$} & $(-0.31,-0.009)$ & $(-0.40,-0.02)$ & $(-0.16,-0.005)$ & $(-0.07,-0.001)$ & $(-0.08,-0.002)$ \\
Typical & $-0.11 *$ & $-0.18 *$ & $-0.07 *$ & $-0.03 *$ & $-0.04 *$ \\
{$[0.90]$} & $(-0.36,-0.003)$ & $(-0.41,-0.009)$ & $(-0.15,-0.003)$ & $(-0.07,-0.001)$ & $(-0.08,-0.002)$ \\
Prone & $-0.14 *$ & $-0.24 *$ & $-0.07 *$ & $-0.03 *$ & $-0.04 *$ \\
{$[0.93]$} & $(-0.31,-0.01)$ & $(-0.49,-0.01)$ & $(-0.15,-0.004)$ & $(-0.06,-0.002)$ & $(-0.07,-0.002)$ \\
\hline \hline
\end{tabular}

Given the presence of violent dissent and an absence of torture the year before, the baseline predicted probabilities when the Gates, et al. variable has a value of zero ranges from 0.88 to 0.93 . The rescaled Polyarchy variable ${ }^{31}$ not only has a larger overall effect-the predicted probabilities range from 0.39 to 0.48 when the Gates, et al. variable is set to its maximum (result not shown)-but the size of the effect is large, grows, and then declines over its distribution. The figure depicts the marginal effect for the typical baseline. Note that this pattern appears to be different from the relationship between democratic institutions and all rights found by Davenport and Armstrong (2004) and Bueno de Mesquita et al. (2005). More specifically, while they report that institutions only influence rights at the highest portion of the former's range, we find here that the change from the 25th to 50th percentile has the largest impact across all three baselines $(-0.18$ to -0.24$)$, and the second largest is the change from zero to the 25 th percentile $(-0.11$ to -0.14$)$. The focus on percentiles-rather than the range of values-is a bit misleading, though, as the figure below shows. We see there that the result is quite similar to that reported in Davenport and Armstrong (2004) and Bueno de Mesquita et al. (2005). ${ }^{32}$

\footnotetext{
${ }^{31}$ As explained in the Appendix, the rescaling involves a logarithmic transformation of the participation component and a truncation of the competition component.

${ }^{32}$ The key point here is that the values are skewed to the right with a long tail: the big change at low percentiles takes place at relatively high values in the range.
} 


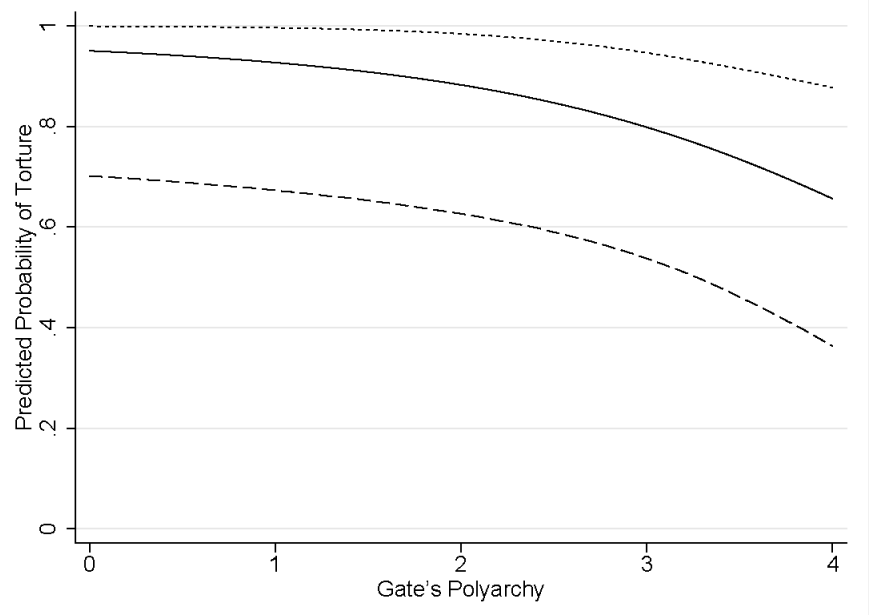

The Polyarchy result suggests that for a linear conceptualization high levels of both competition and participation can provide a non-trivial, though less than desirable, check on an executive's incentive to continue to use torture if there is no violent dissent. Relatively low levels of competition and/or participation produce an imperceptibly small check on the executive. The Gates, et al. result, on the other hand, suggests a rather different dynamic in a distinct setting. An executive that was not using torture and is faced with violent dissent will have a substantial reduction in her incentive to torture given non-linear increases from low levels of competition or participation. The size of the decrease falls off rather dramatically as the product of competition and participation crosses the 50th percentile of the non-linear distribution. Though it is an oversimplification, it is not a distortion of these findings to suggest that high levels of both competition and participation can modestly reduce the incentive to continue torturing when violent dissent is absent, but increases from low levels of either or both can considerably reduce the executive's incentive to start torturing in the presence of violent dissent.

This is an important set of results. Previous results reporting that democracy reduces the incidence of torture (Hathaway 2002) fail to disaggregate democracy into constituent parts. Further, work that does make such distinctions but studies aggregated indicators of state repression have often found that voice reduces repression (Davenport 1999, Davenport and Armstrong 2004, Bueno de Mesquita et al. 2005, Davenport 2007b). Two other studies, however, report results that challenge those findings (Davenport 1997, Richards 1999), and we further refine 
that challenge by showing that elections and the successful transfer of power across partiesas measured by Alvarez et al. (1996) and Bernhard, Nordstrom and Reenock (2001)-do not reduce the probability that a state uses torture. The work of Wantchekon and Healy (1999), Walzer (2004) and Levey (2007) provides cause to expect this, and when we combine it with the argument that dissidents who use violence are unlikely to vote (much less be members of the winning coalition), we have an explanation that can account for the limited impact of voice. Stated more broadly, the failure of 26 of the 28 attempts to establish a relationship between voice and the use of torture suggests that there a robust relationship between the two does not exist.

On the other hand, that the original and rescaled Polyarchy indices do reduce the probability that the executive (tacitly) endorses the use of torture offers a challenge to hypothesis $2 \mathrm{a}$. The Gates, et al. rescaled variable produces surprisingly large effects. Interestingly, the large effects exist in the low to mid rang of the distribution, a finding quite at odds with previous work that has found that only the highest levels of democratic institutions are systematically associated with lower levels of rights violations. This finding suggests not only that the relationship between Dahl's classical two-dimensional conceptualization of democracy and the probability of torture is non-linear, but that moving from very non-competitive party systems to more competitive ones, and very low relative turnout to more mid-range levels has a much larger effect than moving from mid-range to high range levels. Further, shifts from low levels of participation and/or party competition to medium levels apparently only have an effect in the presence of a threat, yet only when the state did not use torture in the preceding year. The ability of the people to use the ballot to constrain the executive's use of torture, then, is very limited indeed.

To summarize, this set of results strongly indicates that blanket statements about the effectiveness of popular suffrage and competitive party systems (i.e., classic democracy) to deter the use of torture have no foundation in evidence from the late 20th Century. This finding will not surprise human rights activists, but it is an important finding with respect to democratic performance, a literature that tends to pay scant attention to state repression. Those who subscribe to a classical, as opposed to liberal, conceptualization of democracy must confront this argument and finding when considering democratic performance. Of course, they have Walzer 
(2004) and Levey (2007) to provide philosophical support for the view that torture is justifiable (though not necessarily justified) in a democracy, and that will perhaps satisfy most who wish to advance the classical perspective.

\subsection{Veto}

We examine seven operational indicators of the veto concept and find that two of them have an impact: both ICRG's Law \& Order variable and Henisz's PolConV indicator reduce the probability that a state uses torture in some settings. Hypothesis 3a anticipates that greater levels of veto will be associated with substantially reduced likelihoods of torture given the absence of violent dissent. Only the Law \& Order variable produced a result consistent with 3a: the other six indicators failed to produce a statistically significant impact. Hypothesis 3b, on the other hand, anticipates a much smaller impact of veto given the presence of violent dissent, and none of our measures of veto produce a result consistent with $3 \mathrm{~b}$. Indeed, six of the measures fail to produce an impact, and the PolConV measure produces a large negative impact in the presence of a threat, but no torture in the preceding year, and no effect when there was no torture in the preceding year. We discuss the two substantive effects and then consider the broader results.

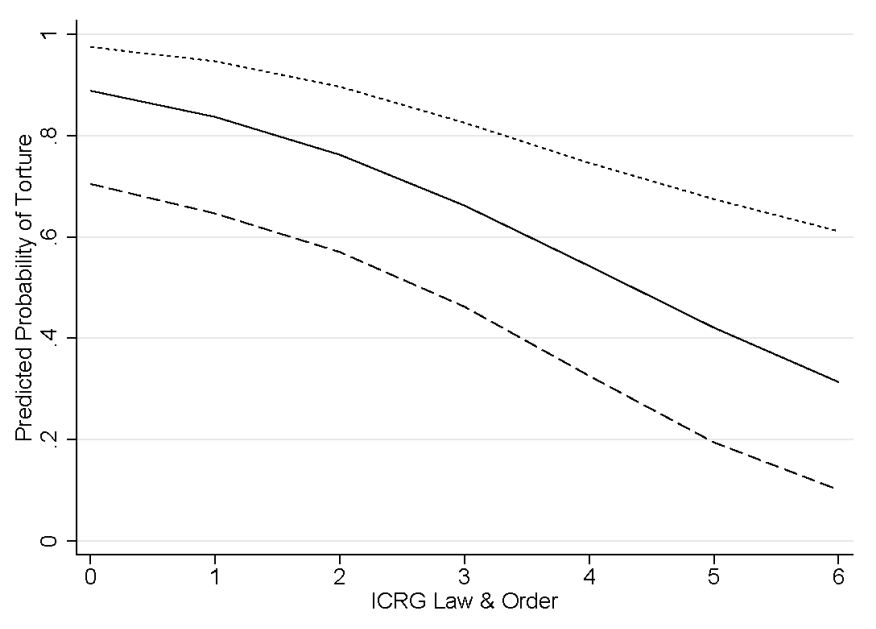


The substantive impact of the Law \& Order variable is depicted in table $7^{33}$ and two figures that depict the marginal effect for the typical baseline case. The variable reduces the probability that the state uses torture only when there is no violent dissident threat. In years following one where the state did not use torture Law \& Order has a large substantive impact reducing the probability from a baseline range of 0.7 to 0.91 to a range of 0.17 to $0.46 .^{34}$

Table 7: Change in Predicted Probability Given Change in Veto (Law \& Order)

\begin{tabular}{lcccc}
\hline \hline \multicolumn{5}{l}{ Absence of Violent Dissent, No Torture } \\
\multicolumn{5}{c}{. } \\
Baseline & 2 to 3 & 3 to 4 & 4 to 5 & 5 to 6 \\
\hline Typical & $-0.12 *$ & $-0.12 *$ & $-0.11 *$ & $-0.08 *$ \\
{$[0.70]$} & $(-0.18,-0.04)$ & $(-0.21,-0.03)$ & $(-0.19,-0.03)$ & $(-0.13,-0.03)$ \\
Prone & $-0.07 *$ & $-0.09 *$ & $-0.12 *$ & $-0.12 *$ \\
{$[0.91]$} & $(-0.13,-0.02)$ & $(-0.18,-0.03)$ & $(-0.21,-0.03)$ & $(-0.20,-0.03)$ \\
\hline
\end{tabular}

No Violent Dissent, Presence of Torture T-1 $_{t-1}$

\begin{tabular}{lcccc} 
Baseline & 2 to 3 & 3 to 4 & 4 to 5 & 5 to 6 \\
\hline Averse & $-0.02 *$ & $-0.03 *$ & $-0.04 *$ & $-0.05 *$ \\
{$[0.93]$} & $(-0.04,-0.005)$ & $(-0.05,-0.004)$ & $(-0.08,-0.005)$ & $(-0.11,-0.05)$ \\
Typical & $-0.01 *$ & $-0.02 *$ & $-0.02 *$ & $-0.03 *$ \\
{$[0.96]$} & $(-0.02,-0.003)$ & $(-0.04,-0.003)$ & $(-0.06,-0.003)$ & $(-0.08,-0.003)$ \\
Prone & $-0.01 *$ & $-0.01 *$ & $-0.02 *$ & $-0.03 *$ \\
{$[0.97]$} & $(-0.02,-0.002)$ & $(-0.03,-0.002)$ & $(-0.05,-0.002)$ & $(-0.08,-0.002)$ \\
\hline \hline
\end{tabular}

When the state engaged in torture in the prior year, however, the impact of the Law \& Order variable is severely curtailed. From a baseline range between 0.93 and 0.97 at a value of two the range drops between 0.80 and 0.91 when Law \& Order has a value of six. While this is a statistically significant effect, it is substantively very small. Of course, as table 3 demonstrated, there is very little variance to explain for countries that used torture in the previous year.

\footnotetext{
${ }^{33}$ We present only two baselines in table 8 because, due to the skewed distribution of some of the variables, the Averse and Typical baselines are sometimes the same in the absence of violent dissent. They are equivalent in this case.

${ }^{34}$ These latter probabilities are not reported in the table, but will be made available in a replication data set upon publication.
} 


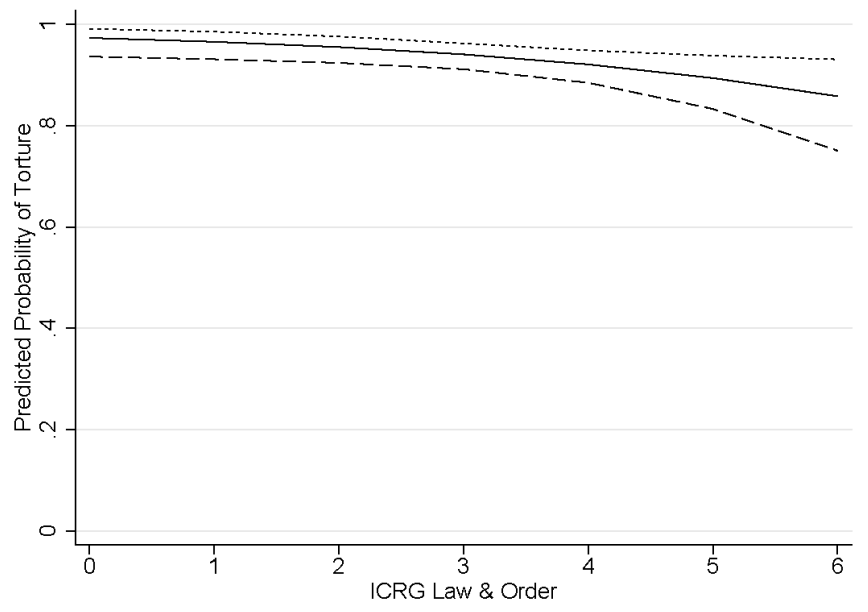

To our surprise the PolConV result contradicts hypothesis $2 \mathrm{~b}$. We expected veto to lower the likelihood of torture when the state was not challenged with violent dissent (2a), and that the impact would be substantially reduced in the presence of violent dissent $(2 \mathrm{~b})$. Yet table 8 records that PolConV does not affect the likely use of torture in the absence of violent dissident activity, ${ }^{35}$ but reduce it considerably when dissidents do engage in violence (though only in years in which the state did not use torture in the preceding year). ${ }^{36}$

Further, the unexpected result holds across all three baselines: most friendly, typical, and most hostile. Finally, the results are substantively large. ${ }^{37}$ In particular, moving from zero through the 75 th percentiles produces strong decreases in the predicted probability. ${ }^{38}$ Contrary to previous work that finds that the effect of democracy only kicks in at high values, the size of the effect of veto dampens strongly as one moves above the 75 th percentile. The figure depicts this marginal effect.

\footnotetext{
${ }^{35}$ We present only two baselines in table 8 because, due to the skewed distribution of some of the variables, the Averse and Typical baselines are sometimes the same in the absence of violent dissent. They are equivalent in this case.

${ }^{36}$ The PolConV variable has no effect when the state used torture in the previous year (results not reported for space considerations).

${ }^{37}$ The cell entries in the table are the change in the predicted probability with the $95 \%$ confidence interval in parentheses below it.

${ }^{38}$ Because Henisz's PolConV has a skewed distribution-roughly $40 \%$ of the cases have a value of zero, indicating an absence of veto points-we calculated change from the minimum to the 43rd percentile, the 43rd to the 50th percentile, the 50 th percentile to the 75 th percentile, the 75 th percentile to the 90 th percentile, and the 90 th percentile to the maximum. Previous research would lead us to anticipate that the effect of veto will not appear until, perhaps, the 75th percentile and above.
} 
Table 8: Change in Predicted Probability Given Percentile Change in Veto (PolConV)

\begin{tabular}{|c|c|c|c|c|c|}
\hline \multicolumn{6}{|c|}{ Absence of Violent Dissent, No Torture $t_{-1}$} \\
\hline Baseline & 0 to $43 \mathrm{rd}$ & $43 \mathrm{rd}$ to $50 \mathrm{th}$ & 50 th to 75 th & 75 th to 90 th & 90 th to $\max$ \\
\hline Typical & -0.02 & -0.07 & -0.003 & -0.008 & -0.003 \\
\hline$[0.33]$ & $(-0.07,0.02)$ & $(-0.26,0.09)$ & $(-0.01,0.01)$ & $(-0.03,0.01)$ & $(-0.01,0.01)$ \\
\hline Prone & -0.01 & -0.07 & -0.004 & -0.01 & -0.005 \\
\hline$[0.58]$ & $(-0.07,0.03)$ & $(-0.10,0.12)$ & $(-0.01,0.01)$ & $(-0.03,0.02)$ & $(-0.01,0.01)$ \\
\hline
\end{tabular}

Presence of Violent Dissent, No Torture $t-1$

\begin{tabular}{lccccc} 
Baseline & 0 to 43rd & 43rd to 50th & 50 th to 75 th & 75 th to 90th & 90 th to max \\
\hline Averse & -0.02 & $-0.05 *$ & $-0.24 *$ & $-0.04 *$ & $-0.13 *$ \\
{$[0.93]$} & $(-0.07,0.003)$ & $(-0.19,-0.0001)$ & $(-0.41,-0.02)$ & $(-0.07,-0.01)$ & $(-0.24,-0.01)$ \\
Typical & $-0.03 *$ & $-0.06 *$ & $-0.29 *$ & $-0.04 *$ & $-0.12 *$ \\
{$[0.93]$} & $(-0.09,-0.001)$ & $(-0.18,-0.0004)$ & $(-0.58,-0.02)$ & $(-0.08,-0.005)$ & $(-0.25,-0.009)$ \\
Prone & $-0.05 *$ & $-0.12 *$ & $-0.41 *$ & $-0.03 *$ & $-0.08 *$ \\
{$[0.93]$} & $(-0.10,-0.01)$ & $(-0.31,-0.0001)$ & $(-0.73,-0.01)$ & $(-0.06,-0.004)$ & $(-0.15,-0.01)$ \\
\hline \hline
\end{tabular}

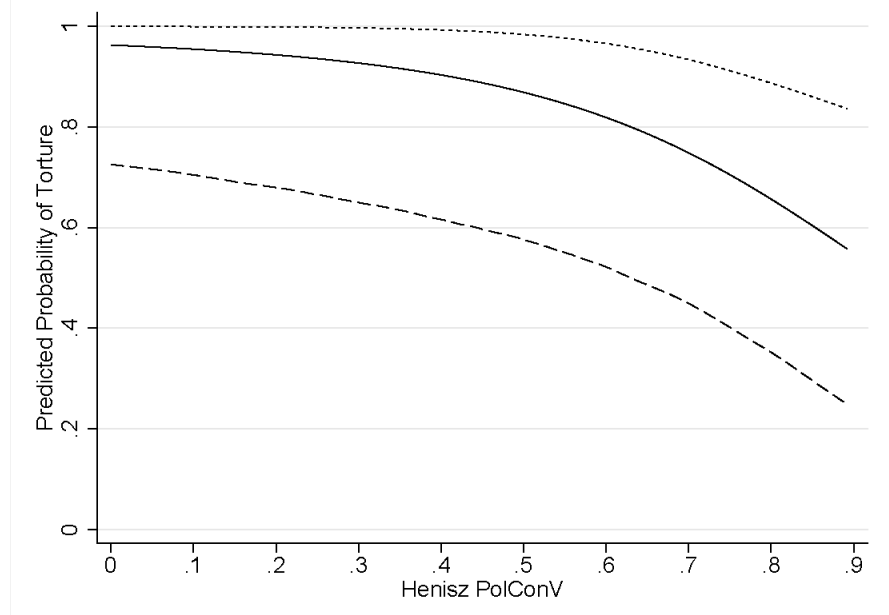

Returning to the hypotheses, $2 \mathrm{a}$ receives support from one of the six indicators, and $2 \mathrm{~b}$ fails to receive any support. Further, $2 \mathrm{~b}$ is contradicted by Henisz's PolConV variable. How might one account for the unexpected PolConV finding, and how confident should we be in either the Law \& Order or PolConV results? In other words, should we take the more scientifically conservative approach and infer that Veto has no impact on the likely use of torture? 
The first question to ask is: why would an executive be increasingly responsive to the potential threat of a veto player's challenge only when she is faced with violent dissent? We had expected that the incentive to use torture would trump the potential veto threat, but the PolConV variable tells a different story. To be sure, it is a normatively appealing story, particularly for champions of liberal democracy and offers an opportunity to consider what differences exist among the operational indicators.

The discussion in the Appendix offers a description of each variable; here we emphasize the differences. PolConV takes into account partisan composition of the legislature vis-á-vis the executive, and it also accounts for an independent judiciary and sub-federal control of fiscal policy. We are least interested in the sub-federal fiscal policy dimension, F, and studied whether it has an independent impact. It does not. PolConIII is the legislative-executive component of PolConV, but it does not have an impact. Finally, the judicial independence sub-component, J, fails to influence the probability that the state uses torture. Thus, we were unable to decompose PolConV and identify a sub-component that was responsible for the result.

DPI's Checks variable, which Henisz recommends as a robustness check for PolConV, also fails to influence the likelihood of torture, as does Polity's executive constraints (XConst) variable. Given these results it is difficult to make a case that the number of veto points in either the legislature or the judiciary are systematically related to the use of torture. The PolConV finding-which is the only variable that is a composite measure of both legislative and judicial veto points-seems to suggest that both are needed, but it needs to be viewed as a provisional finding.

The Law \& Order variable has two components, both of which are judgmentally scored by the staff of a private firm. One dimension is the extent to which the judicial system is free of corruption. The second dimension scores the extent to which the citizenry respects the law (i.e., eschews crime). Each dimension contributes equally to the variable. We are interested in the former, though not the latter. Unfortunately, one cannot decompose the variable into its two dimensions. One wonders, as a result, whether the finding in support of hypothesis two is due to the inclusion of the "order" (or crime) dimension. One imagines that it likely plays some role in the effect. Thus, this result should also be treated with caution. 
There are three take-away points from our examination of several measures of veto points. First, these results suggest that both judicial veto as well as legislative veto points are needed to reduce the likelihood of torture, and then only when the state did not use torture in the previous year and there was violent dissent. That we only observe an effect in the absence of torture in the preceding year suggests that veto-as conceptualized and measured with PolConV-has a deterrent effect on the executive's incentive to torture, but not a reactive one. Second, the lack of an impact of five of the indicators, and the uncertainties about the Law \& Order variable, suggest that the most appropriate inference may be to reject hypothesis $2 \mathrm{a}$. Third, and most importantly, there is limited cause for optimism about the extent to which institutions that produce veto points-an important component of liberal democracy that should constrain the executive-will reduce an executive's incentive to torture. All of the results suggest that when a state is already using torture and is faced with at least one act of violent dissent, veto points are irrelevant. Only when there is no threat, or when the state was not using torture the year prior, do we find some tentative support for the expectation that veto points will constrain a state's use of torture.

\subsection{Freedom of Expression}

Hypothesis four, which anticipates that the effect of freedom of expression will be diminished in the presence of violent dissent, is strongly consistent with the data: the level of free speech reduces the likelihood of torture when there is no violent dissent. More explicitly, the results are consistent with both $4 \mathrm{a}$ and $4 \mathrm{~b}$. The Van Belle measure produces a reduction in the predicted probability regardless of whether the state tortured in the previous year, though only when there is no violent dissent. The CIRI variable produces a statistically significant reduction in the predicted probability of torture when there is no dissent and no torture in the preceding year. Both variables produce substantively large effects. Table 9 shows that given an absence of violent dissent and no torture in the preceding year a change from "restricted" to "free" press reduces the predicted probability from a baseline range between 0.38 and 0.49 to a range between 0.21 and 0.30 . The bottom half of the table reports that the size of the effect is substantially reduced when the state tortured in the previous year: a drop of four to seven percentage points 
from a baseline range between 0.83 and 0.94 .

Table 9: Change in Predicted Probability Given Change in VanBelle Free Press

\begin{tabular}{lc}
\hline \hline No Violent Dissent, No Torture ${ }_{t-1}$ \\
Baseline & Restricted to Free \\
\hline Averse & $-0.19 *$ \\
{$[0.49]$} & $(-0.30,-0.05)$ \\
Typical & $-0.17 *$ \\
{$[0.38]$} & $(-0.28,-0.06)$ \\
Prone & $-0.18 *$ \\
{$[0.43]$} & $(-0.29,-0.07)$ \\
\hline & \\
No Violent & Dissent, But Torture ${ }_{t-1}$ \\
& \\
Baseline & Restricted to Free \\
\hline Averse & $-0.07 *$ \\
{$[0.83]$} & $(-0.21,-0.003)$ \\
Typical & $-0.05 *$ \\
{$[0.94]$} & $(-0.11,-0.003)$ \\
Prone & $-0.04 *$ \\
{$[0.94]$} & $(-0.11,-0.003)$ \\
\hline \hline
\end{tabular}

Table 10 reports the results for the CIRI variable. In the absence of both violent dissent and torture in the preceding year change in the level of press/speech freedom reduces the predicted probability of torture from a baseline range of 0.55 to 0.67 to a range between 0.20 and 0.34 . The size of the drop in predicted probability is similar over both changes (i.e., from "not free" to "partly free," and from "partly free" to "free").

Table 10: Change in Predicted Probability Given Change in CIRI Free Speech/Press

\begin{tabular}{lcc}
\hline \hline \multicolumn{3}{l}{ No Violent Dissent, No Torture $t-1$} \\
Baseline & Not Free to Partly Free & Partly Free to Free \\
\hline Averse & $-0.19 *$ & $-0.15 *$ \\
{$[0.67]$} & $(-0.31,-0.08)$ & $(-0.23,-0.07)$ \\
Typical & $-0.18 *$ & $-0.16 *$ \\
{$[0.61]$} & $(-0.28,-0.05)$ & $(-0.28,-0.05)$ \\
Prone & $-0.18 *$ & $-0.15 *$ \\
{$[0.55]$} & $(-0.30,-0.05)$ & $(-0.23,-0.05)$ \\
\hline \hline
\end{tabular}


As we have seen with many of the other variables, freedom of expression has no effect when the state used torture in the preceding year, regardless of the presence or absence of violent dissent (results not reported for space considerations).

These results are interesting in part because, partially echoing Mueller (1992), they suggest that freedom of expression has an important impact on reducing the likelihood of torture independent of competitive elections. That said the positive normative import of the findings is diminished by the fact that the result only holds in cases when the state had not resorted to torture in the prior year. This suggests that freedom of expression has only a deterrent effect. We discuss the implications of this finding below.

\subsection{Control Variables}

Both of the control variables have the expected effects. Table 11 displays that the instantaneous rate of change in the dependent variable is properly signed (negative for GDP/capita and positive for population) and considerably higher for years following the absence of torture than the presence of torture.

Table 11: Marginal Effect (1st derivative) of Control Variables

\begin{tabular}{lcc}
\hline \hline Variable & No Torture $_{t-1}$ & Torture $_{t-1}$ \\
\hline $\log$ of GDP/capita & $-0.08 *$ & $-0.02 *$ \\
$\log$ of Population & $0.07 *$ & $0.01 *$ \\
\hline \hline
\end{tabular}

\subsection{Discussion}

The empirical analysis highlights one important point and reveals another. First, torture is very common. This is well known among human rights activists, but less well known among students of politics, pundits, and the average citizen. Second, though democracy-and elections in particular-have been found to substantially reduce the abuse of human rights writ large, we have shown that democratic institutions-and elections in particular-are remarkably poor at checking the executive's incentive to use torture. One novel point is important to underline. 
Our analysis has shown that in the context of violent dissent liberal democratic institutions at best deter the (implicit) sanction of torture. Put more directly, once an executive (implicitly) sanctions the use of torture in the context of violent dissident activity, liberal democratic institutions fail to lower the likelihood that she will continue to use it in the following year. This is an unhappy finding for champions of the positive normative impact of democratic institutions, particularly with respect to the protection of human rights.

Einolf $(2007,104-5)$ argues that "[t]oday torture is rarely practiced by liberal democracies against their own citizens, but occasionally practiced by liberal democracies against suspected terrorists and prisoners of war." Our results strongly contradict Einolf's claim that democracies faced with violent threats only resort to torture rarely or occasionally. The data available for this study do not permit one to distinguish between citizens, terrorists and prisoners of war. But we wonder whether such data would support his claim that when democracies use torture, they limit it to these groups. Perhaps they would, but we wonder whether leaders of democratic states restrain themselves as much as Einolf would have us believe.

As a rival possibility we suggest that non-voters in a democracy are at risk to becoming the victims of torture, especially if a small number of an identifiable ethnic (defined broadly) or political group that has high non-voting rates is willing to employ violence to press claims on behalf of the group. Several scholars have maintained that democracy does not eliminate repressive behavior; rather, democracy transforms its application from more overt to covert strategies (e.g., DeJouvenal 1945, Donner 1980, 1990, Cunningham 2004, McPhail, Schweingruber and McCarthy 1998). For example, within the United States, McPhail, Schweingruber and McCarthy (1998) document a phase-shift from World War I to the 1970s away from overt and aggressive repressive techniques employed by police against protestors (involving isolation, large-scale arrests as well as violence [beating, pepper-spraying and shooting]), toward a more negotiated strategy (involving communication, coordination and selected arrests as well as less violence). ${ }^{39}$ Concurrently, Goldstein $(1978)$ and Donner $(1980,1990)$ document a phase-shift

\footnotetext{
${ }^{39}$ Even here one can see an influence of democracy and democratization. Although America maintained numerous elements of a democracy from its founding (e.g., elections, separation of the executive and judicial branches and so forth), it has been argued that it was between the years of World War I (1918) and the 1970s, that the United States solidified its existence as a full-fledged democracy (Goldstein 1978, Hill 1994). During this period, women and blacks were given the right to vote (in 1920 and 1965, respectively), workers were given the right to
} 
upward in the amount of political intelligence (i.e., physical and electronic surveillance) applied by the U.S. government against those challenging it and those uninvolved in these activities. ${ }^{40}$ We do not have adequate data to challenge Einolf with evidence, but we suggest that our study, in combination with the above referenced work, gives cause to call for further investigation of his assertion that democracies rarely torture their own citizens, except when those citizens commit treason.

\section{Conclusion}

The events at Abu Ghraib prison shocked most observers. How could such behavior be associated with one of the most liberal democracies in the world? Opinions on this question are mixed. For some, the torture was explained by idiosyncratic factors (e.g., rogue soldiers and a misunderstanding of political directives) and this type of action was atypical for the U.S. or any other liberal democracy. For others, the events were explained by more systematic factors (e.g., an instrumental response to political threat that led to (implicit) political directives), and it was suggested that this was exactly how liberal democracies like the U.S. would behave under the circumstances. A recent journalistic account strongly supports the latter explanation (Mayer 2006).

To investigate this issue and gauge the influence of liberal democracy on torture, conditioned on civil conflict, we examined 146 countries from 1980 to 1999. Our results contextualize revelations like those of the Abu Ghraib case. By most accounts, the United States was a liberal democracy that did not employ torture. The country experienced terror attacks at the World Trade Center in New York, the Pentagon in Washington, DC, and the plane that was crashed in Pennsylvania. Given the unified partisan control of the executive and legislature our model would predict that a country in this situation would almost certainly resort to torture when interrogating suspected members of Al Qaeda. By most accounts, this is exactly what

strike (1935) and a wave of public forum and protest law was established at a level previously unseen in U.S. history - granting citizens the right to protest in a wide variety of venues: commons, state institutions, airports, university campuses, post offices and parks (McPhail, Schweingruber and McCarthy 1998, 57-59). Indeed, by the 1970s, U.S. democracy had never been as robust.

${ }^{40}$ These tactical shifts have been noted in many other countries as well. 
took place at Abu Ghraib, Guantanamo Bay and diverse prisons where suspected terrorists or their sympathizers were held. The events at these locales were thus neither aberrant nor inexplicable. Quite the contrary, this is generally how states with the highest levels of voice, veto and free speech have behaved in such situations. These results push us to move away from discussion of rogue agents and misunderstood political directives to a more systematic analysis of the role that torture plays within liberal democratic as well as non-democratic governments.

Returning to Walzer (2004) one could argue that the Bush administration responded precisely as it should have. Indeed, the administration has behaved precisely as Walzer's argument would have it behave: they have vigorously denied that the executive has (tacitly) approved the use of torture, despite ample public evidence that it has done so. ${ }^{41}$ That strategy has proven successful: the voting public has yet to penalize Bush. Yet that said, while the administration's efforts to curtail the use of torture have fallen dramatically short of the standards expected by human rights activists, even activists would have to admit that the administration has restricted its use of torture, particularly following the change in the partisan composition of Congress following the 2006 elections (Stolberg 2006).

A second potential implication was put nicely by Diego Gambretta $(2004,33)$ : "the bigger and nastier the threat is (or is thought to be) the harsher are the infringements on civil liberties that can be justified and accepted by the public. One way to defend our civil liberties is to be alert to the forces that could exaggerate and distort the threat." Our study does not consider the interpretation of the threat, but it strikes us as likely that Gambetta has put his finger on an important issue. We have found that given a violent threat the propensity to use torture is not reduced by voice or free speech, and is only constrained by veto when the state had not used torture in the preceding year. Fittingly a considerable amount of post $9 / 11$ public discussion has focused on whether the Bush, Blair, and other Administrations are exaggerating the threat (Williams 2004, Mueller 2005, Winkler 2007). This is an interesting question that

\footnotetext{
${ }^{41}$ See Stolberg (2007) for the most recent administration denial that it condones torture. For evidence that the administration (implicitly) condones the use of torture see, for example, Mayer (2006) who documents the unsuccessful efforts of a senior US Naval Attorney to persuade Secretary of Defense Rumsfeld to revoke his order to use "coercive interrogation" in Guantanamo Bay. That debate took place at the Department of Defense a year prior to the public revelations of torture at Abu Ghraib and since then the Bush Administration has yet to indict a single high ranking official involved in issuing the order to torture detainees.
} 
merits attention in future research.

Turning to the existing literature our research suggests that future inquiry into the "domestic democratic peace" should investigate the influence of democracy on repression conditional upon levels of violent dissent. Human rights activists have long argued that it is one thing for political authorities to respect human rights when they are not being challenged, but it is quite a different situation to maintain this position when existing policies, personnel, institutions and constituents are directly being threatened. Indeed, violent challenges to the state provide the ideal opportunity to observe a government's commitment to human rights and the power of democracy to serve as a mechanism of non-violence and tolerance. Many of us believe that democracies respond to political dissent in very different ways than non-democratic governments, but extant work on the "domestic democratic peace" has failed to consider the possibility that this difference erodes across different levels of threat to the state. There needs to be more systematic investigation of this major revision to the "domestic democratic peace."

Finally, our analysis compels us to further examine not only torture but other forms of repressive behavior as well. For example, previous research tends to aggregate distinct forms of repression: political imprisonment, execution, disappearances, restrictions on speech, association, assembly as well as torture. This ignores the possibility that authorities do not view the techniques as comparable to one another and that there is something unique about different combinations (causal determinants and aftereffects). Although the comment from Davenport $(2004,539)$ that "some governments restrict the rights of those under their territorial jurisdiction, some governments kill their citizens, some restrict and kill, and some do not engage in either" moves us in the right direction, we should move beyond-as well as further into-this point. Simple linear relationships between regime type and the behavior of states may well prove to be woefully inadequate. We have identified one area of inquiry where that is the case and thus joined a small but growing body of work that has produced such findings. Greater theoretical and empirical attention to conditional and non-linear relationships between variables of interest and the disaggregated repressive behavior of states would not only be important for scholars but also for ordinary citizens (who are subject to a wide variety of abuses), those concerned with ending these activities (who need to understand the circumstances under which diverse 
rights are violated), as well as those concerned with treating the victims of these activities (who need to understand what happens in as much detail as possible so that they can better treat those who have suffered).

\section{Appendix}

\subsection{Operational Indicators}

As noted in the text, we have three concepts that we need to measure: voice, veto, and freedom of expression. Below we discuss, in turn, the indicators we use to measure each.

\subsubsection{Voice}

We have identified seven operational measures for our voice concept, by which we mean the extent to which the polity is subject to rule of the people. Dahl (1971) famously identified two dimensions of what he called polyarchy: competition and participation. We understand the former to be the extent to which entry costs to run for political office are the same across all citizens and groups of citizens. The closer to parity, the greater the level of competition. We conceptualize the second dimension to be the extent to which all adults have the right to vote. While none of the measures we use in this study are ideal operational indicators of these two dimensions, all of them measure at least one of the two dimensions, and each has been used by others to measure classical democracy (i.e., rule by the people).

The Political Regimes (aka ACLP) project adopts a classical conceptualization of democracy as a polity where competitive elections determine who holds the executive and legislative government offices (Alvarez et al. 1996, Przeworski et al. 2000). ${ }^{42}$ To be a democracy a regime must meet two criteria: first, the state must select its executive via (indirect) election, and second opposition parties must have a realistic chance of winning elections. ${ }^{43}$ Note that this conceptualization focuses on competitiveness and does not take into consideration Dahl's second dimension: participation. Several of the other indicators we use explicitly measure both

\footnotetext{
${ }^{42}$ We use the recently updated data from Cheibub and Gandhi (2004), and invert their scale to create a variable, aclpreg, that has a value of zero for non-democracies and a value of one for democracies.

${ }^{43}$ More specifically, there must be at least one successful transfer of power from one political party to a second. All regimes that fail to meet these two criteria are coded as dictatorships
} 
dimensions.

Like Przeworski et al. (1996), Bernhard, Nordstrom and Reenock (2001) are interested in the durability of democratic rule. They produce a binary measure of democracy that explicitly builds on Dahl's (1971) minimalist definition. They begin by identifying cases that are coded as democratic by each of the following datasets: Gurr and Jaggers' (1995) Polity III, Gasiorowski's (1996) Political Regime Change Dataset, Freedom House's Freedom in the World, and ACLP's Political Regime Data (p. 783). They then excluded cases that failed to include at least $50 \%$ suffrage rates, those where fraud was judged to be sufficiently large to have changed the outcome, and those cases where extensive violence was judged to influence the outcome (pp. 784-5). ${ }^{44}$ The resulting variable, which we label BNRdemoc, is available online at: http://www.personal.psu.edu/mhb5/data/data.htm.

Vanhanen $(2000 a)$ is the most recent in a string of work on the venerable Polyarchy dataset that he has constructed to measure Dahl's conceptualization of democracy. Vanhanen measures two dimensions: competitiveness and participation. To measure competitiveness he subtracts from 100 the number of legislative seats won by the largest party, thus yielding the number of seats held by the smaller parties. He measures participation with the percentage of the population that cast ballots in the elections (represented over the interval 0 to 100). He then produces his polyarchy index by multiplying the two and dividing the product by 100 .

Gates et al. (2006) are also interested in the duration of regimes, and they use a revised version of Vanhanen's polyarchy index as one measure of institutional characteristics. They raise two issues. First, they note that Vanhanen's Participation dimension is linear, and argue that a log transformation of participation is needed as changes in turnout of, say, five percent are more consequential given a baseline of 20 percent turnout than 75 percent. Second, concerned that Vanhanen's index is biased toward highly fragmented party systems they leave the index unaltered when the plurality winning party garnered more then 70 percent of the vote. When

\footnotetext{
${ }^{44}$ Note that much of the focus of their study is distinguishing among democracies. To make such distinctions they conceptualize along two dimensions: macro-institutional structure and party system. By macro-institutional structure they refer to executive-legislative configuration and, more specifically, the distinction between Presidential and Parliamentary systems (p. 778). They distinguish four types of party systems: predominant party; two party; moderate multiparty; and extreme multiparty. Following Colomer (1995) they conceptualize the interaction of the two dimensions along a single dimension anchored by Majoritarian and Pluralism (with quasi-majoritarian, mixed, and quasi-pluralism rounding out a five category scheme; see figure 1, p. 780).
} 
the plurality winning party polled less than 70 percent they multiply participation by the value of competition divided by 30 percent (pp. 897-8). Put another way, when the plurality winning party receives at least 70 percent of the votes their index is the same as Vanhanen's: (Competition * $\log ($ Participation $)) / 100$, where Competition is 100 minus the number of seats won by the largest party and Participation is the percentage of the population that cast ballots. When the plurality winning party receives less than 70 percent of the vote they weight Participation by 30 percent: (Competition * $\log (($ Participation/0.3) $)) / 100$. We label this variable logpartcomp.

Finally, we use three components of the Polity project's measure of Democracy: Competitiveness of Participation, Competitiveness of Executive Recruitment, and Openness of Executive Recruitment. These three are measures of Dahl's competition dimension. Competitiveness of Participation, parcomp, "refers to the extent to which alternative preferences for policy and leadership can be pursued in the political arena" (Marshall and Jaggers 2005, 25). It has a six point scale ranging over the following values: 0, Unregulated (i.e., no competition); 1 , Repressed; 2, Suppressed; 3, Factional; 4, Transitional; and 5, Competitive.

The second Polity indicator we use, Competitiveness of Executive Recruitment, xrcomp, measures the extent to which political advancement paths provide equal opportunities to nonincumbent individuals and groups. It has three values: 1, Selection (e.g., hereditary); 2, Dual/Transitional (e.g., dual executives, one selected via each); and 3, Competitive (e.g., multiparty elections; Marshall and Jaggers 2005, 20).

Finally, the Openness of Executive Recruitment variable, xropen, measures "the extent [to which] all the politically active population has an opportunity, in principle, to attain the position through a regularized process" (Marshall and Jaggers 2005, 20). It has five values: 0, Unregulated (i.e., power transfers via coercion); 1, Closed (e.g., hereditary succession); 2, Dual Executive/Designation (e.g., two executives, neither elected); 3, Dual Executive/Election (e.g., two executives, one elected); and 4, Open.

\subsubsection{Veto}

We have identified seven indicators of the extent to which actors other than the executive can exercise some level of veto over policy change. Henisz's (2002) Political Constraints project 
offers four measures of veto points in the political system. His PolConIII indicator measures the extent to which the legislature can constrain the executive. He uses a spatial model and by assuming that preferences are uniformly distributed across both chambers and the executive the PolConIII indicator is, in effect, what Heller and McCubbins' 1996 refer to as a procedural (as opposed to substantive) measure of veto points.

Henisz (2002) also produces a substantive veto point variable, PolConV, that adds the judiciary (including sub-Federal level courts) to the legislature, and abandons the uniform distribution assumption of PolConIII. Instead, PolConV weights the number of veto points by partisan composition (i.e., when a veto point is occupied by an actor with the same party affiliation as the executive it does not count).

Henisz's data also provide a binary Judicial Independence variable, J, and a binary subFederal veto point indicator as a separate variable, F. The judicial independence measure is based on two variables discussed below: the Political Risk Group's measure of law and order and the Polity Project's measure of executive constraints. Henisz considers country years with an executive constraint score 2 and (where data are available) a law and order score greater than 3 to have an independent judiciary. The sub-federal indicator, F, focuses on veto over fiscal policy only. To code his F variable Henisz reviewed The Statesman's Yearbook or The Political Handbook of the World and judgmentally assigned a value of one to those country years in which sub-federal entities such as states, provinces, or regions imposed substantive constraints on fiscal policy. The $\mathrm{F}$ variable is of less direct interest for our project, except to the extent to which we can use it to refine our inference with respect to PolConV, for which F is a component.

The World Bank's Database of Political Institutions (DPI) also provides measures of veto points (Keefer 2005). Like PolConV their Checks variable is a measure of substantive veto points, though like PolConIII it focuses only on the legislature. Larger values indicate larger numbers of legislative veto points (Keefer 2005, 18-19).

Political Risk Group is a private firm that produces the International Crisis Risk Guide, a report of indicators of political risk to which many firms subscribe. They produce a Law and Order variable, law_-_order, that is composed of two dimensions, each of which has three possible values ranging from low to high. One dimension, Law, is "an assessment of the strength 
and impartiality of the legal system," while the other, Order, is "an assessment of popular observance of the law" (Political Risk Group nd, 33). The composite law_-_order variable is the sum of the two components and thus ranges from 0 to 6 . The specific coding rules are unavailable as Political Risk Group considers them proprietary. Despite this considerable validity and reliability shortcoming, ${ }^{45}$ these data have been widely used in academic research, in part because their demonstrated market value confer both validity and reliability on them as a large number of Fortune 500 firms continue to subscribe to the service.

The seventh indicator, executive constraints, from the Polity data set, is an ordinal measure with a range from zero to seven. It is one of several sub-components to the well known Democracy and Autocracy variables. Executive constraints, xconst, "refers to the extent of institutionalized constraints on the decisionmaking powers of chief executives, whether individuals or collectivities" (Marshall and Jaggers 2005, 23). A value of one indicates unlimited executive authority; three represents slight to moderate limitations; five indicates substantial limitations; and seven represents institutions where the executive is at parity with, or subordinate to, other actors. $^{46}$

\subsubsection{Freedom of Expression}

We use two measures of the freedom of expression. ${ }^{47}$ The CIRI measure focuses on restrictions on both speech and press. It has three values: 0 , no restrictions; 1 , some restrictions; and 2, complete restriction (Cingranelli and Richards 2004a, 16). As noted in the text, we reverse the order of the scale so that it is an indicator of freedom rather than restriction. The US State Department Country Reports on Human Rights Practices is the source for these data.

Van Belle's data focuses exclusively on press freedom. He uses a five category scale, but cautions that "these categories should probably be collapsed into a dichotomous measure of free and restricted presses" (Van Belle 2000, 141). The values in his scale are: 0, nonexistent; 1,

\footnotetext{
${ }^{45}$ Though only nine of 2,355 country-years with valid values have a value of zero, 205 have a value of one. It is unclear how any country-year could have a value less then two: low on Law and low on Order should produce $1+1=2$.

${ }^{46}$ The values two, four, and six are used to code polities that are intermediate between one and three, three and five, and five and seven, respectively.

${ }^{47}$ The Freedom House project also has a freedom of press indicator, but it only covers a limited portion of our study's temporal domain (Verify This!!), so we do not include it.
} 
free; 2, imperfectly free; 3, restricted; and 4, controlled. We follow Van Belle and assign those country-years with a value of 0,3 or 4 as ineffective/restricted and those country-years with a value of 1 or 2 as free. Van Belle relies upon the International Press Institute's World Press Freedom Review and a wide variety of country histories and other texts (p. 138). 


\section{References}

Abbott, Kenneth W. and Duncan Snidal. 2000. "Hard and Soft Law in International Governance." International Organization 54(3):421-456.

Alvarez, Michael, Jose Cheibub, Fernando Limongi and Adam Przeworski. 1996. "Classifying Political Regimes." Studies in Comparative International Development 31(2):1-37.

Amnesty International. 1984. Torture in the Eighties: An Amnesty International Report. New York: Amnesty International.

Andrews, William. 1991. Old Time Punishments. New York: Dorsey Press.

Arendt, Hannah. 1973. The Origins of Totalitarianism. Harvest Books.

Banks, Arthur S. 2001. "Cross-National Time-Series Data Archive.". Binghamton: Center for Social Analysis.

URL: http://www.databanks.sitehosting.net/

Beck, Nethaniel, David Epstein, Simon Jackman and Sharyn O'Halloran. 2002. "Alternative Models of Dynamics in Binary Time-Series Cross-Section Models: The Examples of State Failure.". Prepared for the 2001 Annual Meeting for the Society for Political Methodology Atlanta, GA.

Bernhard, Michael, Timothy Nordstrom and Christopher Reenock. 2001. "Economic Performance, Institutional Intermediation and Democratic Breakdown." Journal of Politics $63(3): 775-803$.

Bollen, Kenneth A. 1992. Political Rights and Political Liberties: An Evaluation of Human Rights Measures 1950-1984. In Human Rights and Statistics: Setting the Record Straight, ed. T B Jabine and Richard Pierre Claude. Philadelphia: University of Penssylvania Press pp. ?-?

Bowden, Mark. 2003. "The Dark Art of Interrogation: A Survey of the Landscape of Persuasion." The Atlantic Monthly 292(3).

Brambor, Thomas, William Clark and Matt Golder. 2006. "Understanding Interaction Models: Improving Empirical Analyses." Political Analysis 14(1):63-82.

Braumoeller, Bear F. 2004. "Hypothesis Testing and Multiplicative Interaction Terms." International Organization 58(4):807-820.

Brody, Reed. 2004. The Road to Abu Ghraib. New York: Human Rights Watch. http://hrw.org/reports/2004/usa0604/.

Bueno de Mesquita, Bruce, Alastair Smith, Randolph M. Siverson and James M. Morrow. 2003. The Logic of Political Survival. Cambridge: MIT Press.

Bueno de Mesquita, Bruce, George W. Downs, Alastair Smith and Feryal Marie Cherif. 2005. "Thinking Inside the Box: A Closer Look at Democracy and Human Rights." International Studies Quarterly 49:439-457. 
Cheibub, José Antonio and Jennifer Gandhi. 2004. "Classifying Political Regimes: A Six Fold Classification of Democracies and Dictatorships." Dataset, Yale University.

Chuckman, John. 2004. "Peep Show on Capitol Hill: Sex, Lies and Videotapes." Counterpunch. URL: http://www.counterpunch.org/chuckman05152004.html

Cingranelli, David L. and David L. Richards. 1999a. "Measuring the Level, Pattern and Sequence of Government Respect for Physical Integrity Rights." International Studies Quarterly 43(2):407-418.

Cingranelli, David L. and David L. Richards. 1999b. "Respect for Human Rights after the End of the Cold War." Journal of Peace Research 36(5):511-534.

Cingranelli, David L. and David L. Richards. 2004a. "The Cingranelli Richards (CIRI) Human Rights Database Coding Manual." available online at: http://ciri.binghamton.edu/documentation.asp.

Cingranelli, David L. and David L. Richards. 2004b. "The Cingranelli-Richards (CIRI) Human Rights Dataset.". http://www.humanrightsdata.org, accessed 12-1-2004.

Collier, David and Steven Levitsky. 1997. "Research Note: Democracy with Adjectives: Conceptual Research in Comparative Politics." World Politics 43(3):430-451.

Colomer, Josep M. 1995. "Strategies and Outcomes in Eastern Europe." Journal of Democracy $6(2): 74-85$.

Cunningham, David. 2004. There's Something Happening Here; The New Left, The Klan and FBI Counter Intelligence. Berkeley: University of California Press.

Dahl, Robert. 1971. Polyarchy: Participation and Opposition. New Haven: Yale University Press.

Dallin, Alexander and George Breslauer. 1970. Political Terror in Communist Systems. Stanford: Stanford University Press.

Davenport, Christian. 1995. "Multi-Dimensional Threat Perception and State Repression: An Inquiry Into Why States Apply Negative Sanctions." American Journal of Political Science $39(3): 683-713$.

Davenport, Christian. 1997. "From Ballots to Bullets: An Empirical Assessment of How National Elections Influence State Uses of Political Repression." Electoral Studies 16(4):517-540.

Davenport, Christian. 1998. "Liberalizing event or lethal episode?: an empirical assessment of how national elections affect the suppression of political and civil liberties." Social Science Quarterly 79(2):321-341.

Davenport, Christian. 1999. "Human Rights and the Democratic Proposition." Journal of Conflict Resolution 43(1):92-116.

Davenport, Christian. 2004. "Human Rights and the Promise of Democratic Pacification." International Studies Quarterly 48(3):539-560. 
Davenport, Christian. 2007a. "State Repression and Political Order." Annual Review of Political Science 10:1-27.

Davenport, Christian. 2007b. State Repression and the Domestic Democratic Peace. New York: Cambridge University Press.

Davenport, Christian and David Armstrong. 2004. "Democracy and the Violation of Human Rights: A Statistical Analysis from 1976-1996." American Journal of Political Science 48(3):538-554.

DeJouvenal, Bertrand. 1945. On Power: Its Nature and the History of Its Growth. Boston: Beacon Press.

Dershowitz, Alan M. 2002. Why Terrorism Works. New Haven: Yale University Press.

DeTocqueville, Alexis. 1835. Democracy in America. New York: Doubleday. Translated by G. Lawrence and JP Mayer.

Donner, Frank. 1980. The Age of Surveillance: The Aims and Methods of America's Political Intelligence System. New York: Knopf.

Donner, Frank. 1990. Protectors of Privilege: Red Squads and Police Repression in Urban America. Los Angeles: University of California Press.

Drakos, Konstantino and Andreas Gofas. 2006. "The Devil You Know but Are Afraid to Face: Underreporting Bias and Its Distorting Effects on the Study of Terrorism." Journal of Conflict Resolution 50(5):714-735.

Einolf, Christopher J. 2007. "The Fall and Rise of Torture: A Comparative and Historical Analaysis." Sociological Theory 25(2):101-121.

Fearon, James and David Laitin. 2003. "Ethnicity, Insurgency and Civil War." American Political Science Review 97(1):75-90.

Fein, Helen. 1995. "More Murder in the Middle: Life-Integrity Violations and Democracy in the World." Human Rights Quarterly 17:170-191.

Fein, Robert A., Paul Lehner and Bryan Vossekuil. 2006. Educing Information. Interrogation: Science and Art. Washington, DC: NDIC Press.

URL: http://www.fas.org/irp/dni/educing.pdf

Filkens, Dexter. 2004. "The Struggle for Iraq: The Commanders; A Prison Tour With Apologetic Generals." The New York Times p. A16.

Foucault, Michel. 1979. Discipline and Punish: The Birth of the Prison. New York: Vintage Books.

Gallie, W. B. 1956. "Essentially Contested Concepts." Proceedings of the Aristotelian Society (51):167-198.

Gambretta, Diego. 2004. "Reason and Terror: Has 9/11 Made it Hard to Think Straight?" Boston Review pp. 32-36. 
Gartner, Scott S. and Patrick M. Regan. 1996. "Threat and Repression: The Non-Linear Relationship between Government and Opposition Violence." Journal of Peace Reearch 33(3):273288.

Gates, Scott, Håvard Hegre, Mark P. Jones and Håvard Strand. 2006. "Institutional Inconsistency and Political Instability: The Duration of Polities." American Journal of Political Science 50(2):893-908.

Gibney, Mark and Matthew Dalton. 1996. "The Political Terror Scale." Policy Studies and Developing Nations 4:73-84.

Giddens, Anthony. 1987. The Nation-State and Violence: A Contemporary Critique of Historical Materialism (vol.2). Berkeley: University of California Press.

Gilligan, Michael J. and Nathaniel Nesbitt. 2006. Do Norms Reduce Torture? Paper presented at the Annual Meeting of the American Political Science Association.

Goldstein, Robert J. 1978. Political Repression in Modern America. Cambridge: Schenkman Publishing Company.

Goodman, Ryan and Derek Jinks. 2003. "Measuring the Effects of Human Rights Treaties." European Journal of International Law 14(1):171-184.

Gurr, Ted. 1986. The Political Origins of State Violence and Terror: A Theoretical Analysis. In Government Violence and Repression: An Agenda for Research, ed. Michael Stohl and George Lopez. New York: Greenwood Press.

Harff, Barbara. 2003. "No Lessons Learned from the Holocaust: Assessing Risks of Genocide and Political Mass Murder Since 1955." American Political Science Review 97(1):57-74.

Hathaway, Oona A. 2002. "Do Human Rights Treaties Make a Difference?" Yale Law Journal 111:1935-2042.

Hathaway, Oona A. 2003. "The Cost of Commitment." Stanford Law Review 55:1821-1862.

Hathaway, Oona A. 2004. The Promise and Limits of the International Law of Torture. In Torture, ed. Sanford Levinson. New York: Oxford University Press pp. 199-212.

Hathaway, Oona A. and Daniel E. Ho. 2004. Characterizing Measurement Error in Human Rights. Paper presented at the annual meeting of the American Political Science Association.

Hegre, Håvard, Tanja Ellingsen, Scott Gates and Nils Peter Gleditsch. 2001. "Toward a Democratic Civil Peace? Democracy, Political Change and Civil War, 1916-1992." American Political Science Review 95:33-48.

Heller, William B. and Matthew D. McCubbins. 1996. "Politics, Institutions and Outcomes: Electricity Regulation in Argentina and Chile." Journal of Policy Reform 1(4):357-387.

Henderson, Conway. 1991. "Conditions Affecting the Use of Political Repression." Journal of Conflict Resolution 35:120-142.

Henisz, Witold J. 2002. "The institutional environment for infrastructure investment." Industrial and Corporate Change 11(2):355-389. 
Hersh, Seymour M. 2004. Chain of Command: The Road from 9/11 to Abu Ghraib. New York: HarperCollins.

Hersh, Seymour M. 2007. "The General's Report." The New Yorker pp. 58-79.

Hibbs, Douglas. 1973. Mass Political Violence. New York: Wiley.

Hill, Kim. 1994. Democracy in the Fifty States. Lincoln: University of Nebraska Press.

Ignatieff, Michael. 1978. A Just Measure of Pain: The Penitentiary in the Industrial Revolution, $1750-1850$.

Keefer, Philip. 2005. DPI 2004, Database of Political Institutions: Changes and Variable Definitions. Washington, DC: Development Research Group, The World Bank. http://siteresources.worldbank.org/INTRES/Resources/DPI2004_variable-definitions.pdf.

King, Gary. 1989. Unifying Political Methodology. Princeton: Princeton University Press.

King, Gary and Langche Zeng. 2006. "The Dangers of Extreme Counterfactuals." Political Analysis 14(2):131-159.

King, Gary and Langche Zeng. $2007 a$. "Detecting Model Dependence in Statistical Inference: A Response." International Studies Quarterly 51(1):231-241.

King, Gary and Langche Zeng. 2007b. "When Can History be Our Guide? The Pitfalls of Counterfactual Inference." International Studies Quarterly 51(1):183-210.

King, Gary, Robert Keohane and Sidney Verba. 1994. Designing Social Inquiry. Princeton: Princeton University Press.

Krain, Matthew. 1997. "State-Sponsored Mass Murder: A Study of the Onset and Severity of Genocides and Politicides." Journal of Conflict Resolution 41(3):331-360.

Levey, Graham Brahm. 2007. "Beyond Durkheim: A Comment on Steven Lukes's 'Liberal Democratic Torture'." British Journal of Political Science 37(3):567-570.

Levinson, Sanford. 2004. Torture: A Collection. New York: Oxford University Press.

Li, Quan. 2005. "Does Democracy Promote or Reduce Transnational Terrorist Incidents?" Journal of Conflict Resolution 49(2):278-297.

Lichbach, Mark. 1987. "Deterrence or Escalation? The Puzzle of Aggregate Studies of Repression and Dissent." Journal of Conflict Resolution 31:266-297.

Long, J. Scott. 1997. Regression Models for Categorical and Limited Dependent Variables. Thousand Oaks: Sage Publications.

Marshall, Monte and Keith Jaggers. 2005. Polity IV Project: Dataset Users Manual. Center for International Conflict Data Management. available online at: http://www.cidcm.umd.edu/polity/.

Marshall, Monty and Keith Jaggers. 2001. Polity IV Project: Political Regime Characteristics and Transitions, 1800-1999. Data Users Manual. Available online at: http://www.cidcm.umd.edu/inscr/polity/polreg.htm. 
Mayer, Jane. 2006. "The Memo: How an Internal Effort to Ban the Abuse and Torture of Detainees was Thwarted." The New Yorker pp. 32-41.

McPhail, Clark, David Schweingruber and John McCarthy. 1998. Policing Protest in the United States: 1960-1995. In Policing Protest: The Control of Mass Demonstrations in Western Democracies, ed. Donatella della Porta and Herbert Reiter. Minneapolis: University of Minnesota Press.

Millett, Kate. 1994. The Politics of Cruelty: An Essay on the Literature of Political Imprisonment. New York: W.W. Norton and Company.

Mitchell, Neil J. and James M. McCormick. 1988. "Economic and Political Explanations of Human Rights Violations." World Politics 40:476-498.

Mueller, John. 1992. "Democracy and Ralph's Pretty Good Grocery: Elections, Equality, and Minimal Human Being." American Journal of Political Science 36(4):983-1003.

Mueller, John. 2005. "Simplicity and Spook: Terrorism and the Dynamics of Threat Exaggeration." International Studies Review 6(2):208-234.

Peters, Edward. 1985. Torture. Oxford: Basil Blackwell.

Poe, Steven and C. Neal Tate. 1994. "Repression of Personal Integrity Rights in the 1980's: A Global Analysis." American Political Science Review 88:853-872.

Political Risk Group. nd. The International Country Risk Guide, Part II. New York: . http://www.columbia.edu/acis/eds/dgate/pdf/C3743.icrgextract_busguide04.pdf.

Powell, Emilia J. and Jeffrey K. Staton. 2007. Domestic Judicial Institutions and Human Rights Treaty Violation. Presented at the Annual meeting of the Southern Political Science Association.

Przeworski, Adam, Michael Alvarez, José Antonio Cheibub and Fernando Limongi. 1996. "What Makes Democracies Endure?" Journal of Democracy 7(1):31-55.

Przeworski, Adam, Michael Alvarez, José Antonio Cheibub and Fernando Limongi. 2000. Democracy and Development: Political Insititutions and Well-Being in the World, 19501990. New York: Cambridge University Press.

Quiroga, Jose and James M. Jaranson. 2005. "Politically-motivated torture and its survivors: A desk study review of the literature." Torture Journal 15(2-3):1-111.

Ray, James Lee. 2003. "Explaining Interstate Conflict and War: What Should be Controlled For?" Conflict Management and Peace Science 20(2):1-31.

Regan, Patrick and Errol Henderson. 2002. "Democracy, Threats and Political Repression in Developing Countries: Are Democracies Internally Less Violent?" Third World Quarterly 23(1):119-136.

Rejali, Darius. 1994. Torture and Modernity: Self, Society and State in Modern Iran. Boulder, CO: Westview Press. 
Rejali, Darius. 2007. Torture and Democracy. Princeton, New Jersey: Princeton University Press.

Richards, David L. 1999. "Perilous Proxy: Human Rights and the Presence of National Elections." Social Science Quarterly 80(4):648-668.

Ron, James. 1997. "Varying Methods of State Violence." International Organization 51(2):275300.

Rosato, Sebastian. 2003. "The Flawed Logic of Democratic Peace Theory." American Political Science Review 97(4):585-602.

Sambanis, Nicholas. 2004. "What Is Civil War? Conceptual and Empirical Complexities of an Operational Definition." Journal of Conflict Resolution 38(6):814-858.

Sambanis, Nicholas and Michael W. Doyle. 2007. "No Easy Choices: Estimating the Effects of United Nations Peacekeeping." International Studies Quarterly 51(1):217-226.

Sarkees, Meredith Reid. 2000. "The Correlates of War Data on War: An Update to 1997." Conflict Management and Peace Science 18(1):123-144.

Schrodt, Philip A. 2007. "Of Dinosaurs and Barbecue Sauce: A Comment on King and Zeng." International Studies Quarterly 51(1):211-215.

Schumpeter, Joseph A. 1962. Capitalism Socialism and Democracy. 3 ed. New York: Harper Torchbooks.

Singer, J. David and Melvin Small. 1972. The Wages of War, 1816-1965: A Statistical Handbook. New York: John Wiley.

Solzhenitsyn, Aleksandr. 1974. The Gulag Archipelago, 1918-1956: An Experiment in Literary Investigation, 3 vols. New York: Harper and Row.

Stevenson, Richard W. 2004. "The Struggle for Iraq: The President; Bush, on Arab TV, Denounces Abuse of Iraqi Captives." The New York Times p. A1.

Stohl, Michael. 1983. "The International Network of Terrorism." Journal of Peace Reearch 20(1):59-66.

Stolberg, Sheryl Gay. 2006. "Bush Signs New Rules to Prosecute Terror Suspects." The New York Times pp. E1-2.

Stolberg, Sheryl Gay. 2007. "Bush Says Interrogation Methods Arent Torture." The New York Times p. A1.

Taylor, Charles and David Jodice. 1983. World Handbook of Political and Social Indicators III. New Haven: Yale University Press.

Tomz, Michael, Jason Wittenberg and Gary King. 2003. "CLARIFY: Software for Interpreting and Presenting Statistical Results." Available at: http://gking.harvard.edu/. Version 2.1.

Van Belle, Douglas A. 2000. Press Freedom and Global Politics. Westport: Praeger. 
Vanhanen, Tatu. 2000a. "A New Dataset for Measuring Democracy, 1810-1998." Journal of Peace Research 37(2):251-265.

Vanhanen, Tatu. 2000b. "The Polyarchy Dataset: Vanhanen's Index of Democracy.".

URL: http://www.prio.no/page/Project_detail//9649/42472.html

Walter, Eugene. 1969. Terror and Resistance. New York: Oxford University Press.

Walzer, Michael. 2004. Political Action: The Problem of Dirty Hands. In Torture: A Collection, ed. Sanford Levinson. New York: Oxford University Press pp. 61-76.

Wantchekon, Leonard and Andrew Healy. 1999. "The 'Game' of Torture." Journal of Conflict Resolution 43(5):596-609.

Williams, Bruce A. 2004. "War Rhetoric's Toll on Democracy." The Chronicle of Higher Education .

Winkler, Carol. 2007. "Parallels in Preemptive War Rhetoric: Reagan on Libya; Bush 43 on Iraq." Rhetoric \& Public Affairs 10(2):303-334.

Zakaria, Fareed. 1997. "The Rise of Illiberal Democracy." Foreign Affairs 76:22-43.

Zanger, Sabine C. 2000. "A Global Analysis of the Effect of Political Regime Changes on Life Integrity Violations, 1977-1993." Journal of Peace Research 37(2):213-233.

Zimbardo, Philip. 2007. The Lucifer Effect: Understanding How Good People Turn Evil. Random House.

Zwerman, Gilda. 1988. "Special Incapacitation: The Emergence of a New Correctional Facility for Women Political Prisoners." Social Justice 15(1):31-47.

Zwerman, Gilda. 1990. "Domestic Counterterrorism: U.S. Government Responses to Political Violence on the Left in the Reagan Era." Social Justice 16(2):31-63. 